Q7) Center for Intersectionality AFRICAN AMERICAN

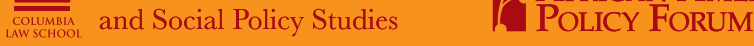

\title{
BLACK GIRLS MATTER: PUSHED OUT, OVERPOLICED AND UNDERPROTECTED
}

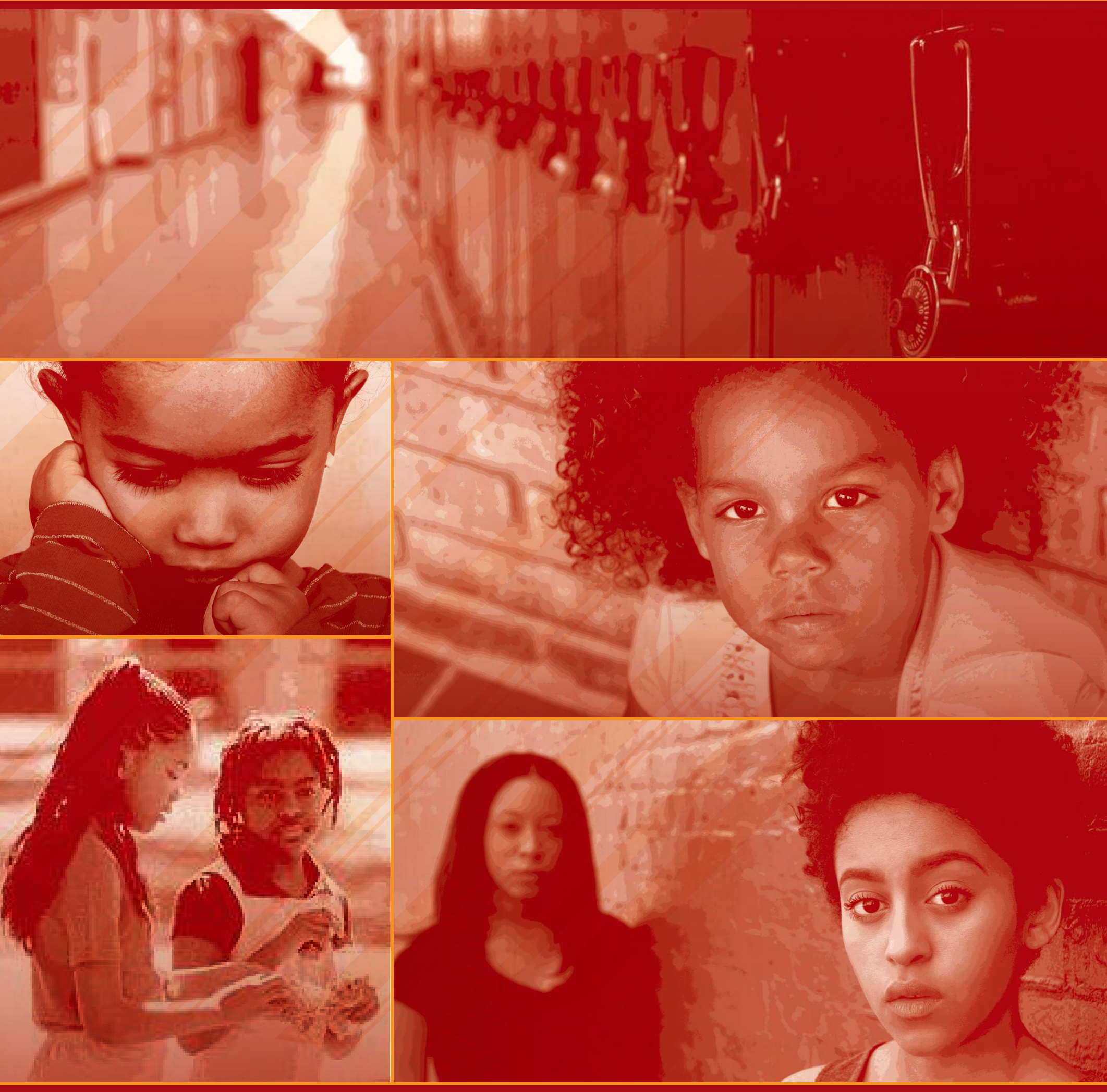




\title{
BLACK GIRLS MATTER: PUSHED OUT, OVERPOLICED AND UNDERPROTECTED
}

\author{
AFRICAN AMERICAN POLICY FORUM
}

www.aapf.org// info@aapf.org

\section{CENTER FOR INTERSECTIONALITY AND SOCIAL POLICY STUDIES}

www.intersectionality-center.org // intersectionality@columbia.law.edu

\author{
435 West 116th St. - Box E7 \\ New York, NY 10027
}

\section{By Kimberlé Williams Crenshaw \\ wiтн Priscilla Ocen and Jyoti Nanda}

ACKNOWLEDGMENTS
We would like to thank the following individuals
for their editorial and research contributions:
Catarina Prata
Monique Morris
Scott Dewey
Luke Harris
Rachel Gilmer
Heidi Hartmann
Kegan Sheehan
Michael Gnat

GRAPHIC DESIGN

Tony Carranza

We are greatly indebted to the young women who participated in our Kings County, NY and Suffolk County, MA focus groups as well as the adult stakeholders who sat for interviews. This report strives to integrate and elevate the experiences of Black girls as well as other girls of color-a feat that would have been impossible without committed student and stakeholder participation.

We acknowledge the generous support of The Schott Foundation for Public Education which underwrote the research that is summarized in this report. We especially wish to express our gratitude to Nakisha Lewis whose tireless work at the Schott Foundation on behalf of girls of color made this report possible, and to Cassie Schwerner who has continued to lift up this work. The support of The Atlantic Philanthropies, NoVo Foundation and Open Society Foundation's Soros Justice Fellowship is also gratefully acknowledged.

We also acknowledge the Critical Race Studies Program and the Law Review of UCLA Law School, whose 2012 symposium, "Overpoliced and Underprotected: Women, Race and Criminalization," served as the catalyst for this report.

To obtain a paper copy of this report, please contact: info@aapt.org

C2015 African American Policy Forum • Center for Intersectionality and Social Policy Studies

The opinions and conclusions expressed herein do not necessarily represent the views of these funders. 


\section{TABLE OF CONTENTS}

$\begin{array}{ll}\text { PREFACE } & 4\end{array}$

EXECUTIVE SUMMARY 8

THE RACIALIZED \& GENDERED

CONTOURS OF THE CRISIS

THE HIDDEN TOLL OF RACE ON BLACK

GIRLS: WHAT THE DATA SUGGEST

16

WHAT GIRLS KNOW

26

WHAT CAN BE DONE? RECOMMENDATIONS FOR

ADDRESSING THE NEEDS OF GIRLS OF COLOR

41

CONCLUSION

44

APPENDIX DATA ANALYSIS

45

ENDNOTES

48 


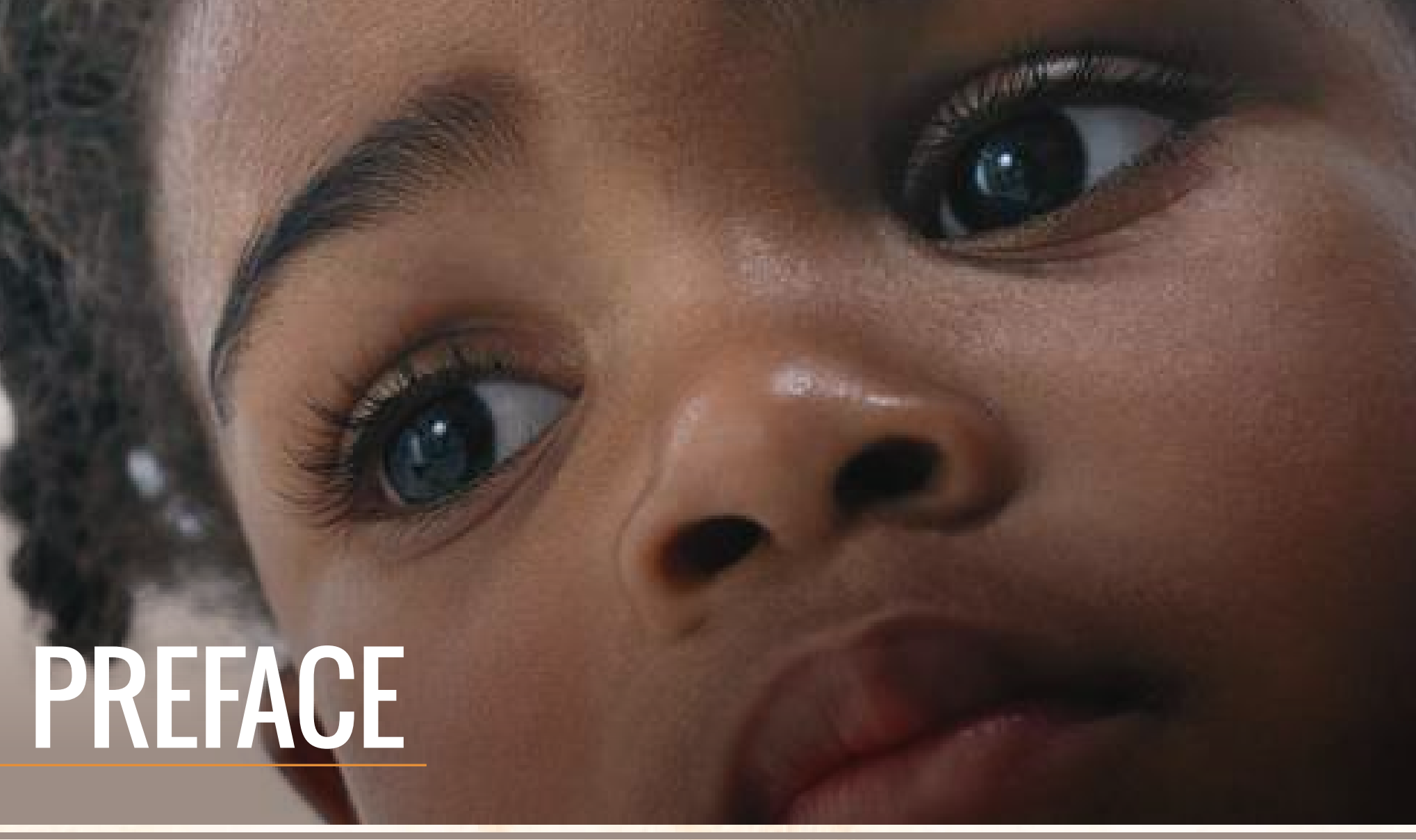

In 2014, a 12-year-old girl faced expulsion and criminal charges after writing "hi" on a locker room wall of her Georgia middle school," and a Detroit honors student was suspended for her entire senior year for accidently bringing a pocketknife to a football game. ${ }^{2}$

In 2013, an 8-year-old girl in Illinois was arrested for acting out, ${ }^{3}$ and a 16-year-old girl in Alabama who suffers from diabetes, asthma, and sleep apnea was hit with a book by her teacher after she fell asleep in class. The student was later arrested and hospitalized due to injuries she sustained in her interaction with the police. ${ }^{4}$ Also in 2013, a 16-year-old in Florida was arrested when an experiment she tried on school grounds caused a small explosion, ${ }^{5}$ and a 12 -year-old girl was threatened with expulsion from an Orlando private school unless she changed the look of her natural hair. ${ }^{6}$

In 2007, a 6-year-old girl was arrested in a Florida classroom for having a tantrum. ${ }^{7}$ Later that year, a 16-year-old girl was arrested in a California school for dropping cake on the floor and failing to pick it up to a school officer's satisfaction. ${ }^{8}$ 
In each of these scenarios - and in others across the country - African American girls were on the receiving end of punitive, zero-tolerance policies $^{9}$ that subjected them to violence, arrest, suspension and/or expulsion.

It is well-established in the research literature and by educational advocates that there is a link between the use of punitive disciplinary measures and subsequent patterns of criminal supervision and incarceration. Commonly understood as the "school-to-prison pipeline," this framework highlights the ways that punitive school policies lead to low achievement, system involvement, and other negative outcomes. Efforts to reverse the consequences of this pipeline have typically foregrounded boys of color, especially Black ${ }^{10}$ boys, who are suspended or expelled more than any other group.

As the cases outlined above demonstrate, punitive disciplinary policies also negatively impact Black girls and other girls of color. Yet much of the existing research literature excludes girls from the analysis, leading many stakeholders to infer that girls of color are not also at risk.

Against the backdrop of the surveillance, punishment, and criminalization of youth of color in the United States, Black Girls Matter: Pushed Out, Overpoliced, and Underprotected seeks to increase awareness of the gendered consequences of disciplinary and push-out policies for girls of color, and, in particular, Black girls. ${ }^{11}$ The report developed out of a critical dialogue about the various ways that women and girls of color are channeled onto pathways that lead to underachievement and criminalization. At the 2012 UCLA School of Law Symposium, "Overpoliced and Underprotected: Women, Race, and Criminalization," 12 formerly incarcerated women, researchers, lawyers, and advocates came together to address the alarming patterns of surveillance, criminal supervision, and incarceration among women and girls of color. The symposium was an effort to investigate the specific contours of race and gender in relationship to zero-tolerance policies, social marginalization, and criminalization. 
The challenge is real. Black girls receive more severe sentences when they enter the juvenile justice system than do members of any other group of girls, and they are also the fastest growing population in the system. Despite these troubling trends, there is very little research highlighting the short and long term effects of overdiscipline and pushout on girls of color. ${ }^{13}$

Emerging from the 2012 symposium, it was clear that serious interventions were necessary to alleviate the knowledge desert that exists around the lives and experiences of Black women and girls.

Thus, we are pleased that the Schott Foundation has recognized the need to address the impact of zero-tolerance policies on girls of color along with other factors that seriously undermine their achievement and well-being. The foundation's vision allowed us to hear directly from young women of color about the disciplinary and push-out policies they experience in Boston and New York City public schools.

This modest but long-overdue effort to cast light onto the lives of marginalized girls should be replicated and expanded across the nation. Ideally, the conversation Black Girls Matter: Pushed Out, Overpoliced, and Underprotected engenders within communities and among philanthropists, policy makers, stakeholders, and advocates will lead to the inclusion of girls in efforts to address school discipline, push-out, and the pathways to incarceration, poverty, and low-wage work. We are especially hopeful that ongoing efforts to resolve the crisis facing boys of color will open up opportunities to examine the challenges facing their female counterparts.

We encourage those who are concerned about the current crisis to broaden their understanding of the ways that gender contributes to the particular risks that students of color face, and to commit to enhancing resources to ensure that all our youth have the opportunity to achieve.

- Kimberlé Crenshaw, Jyoti Nanda and Priscilla Ocen 



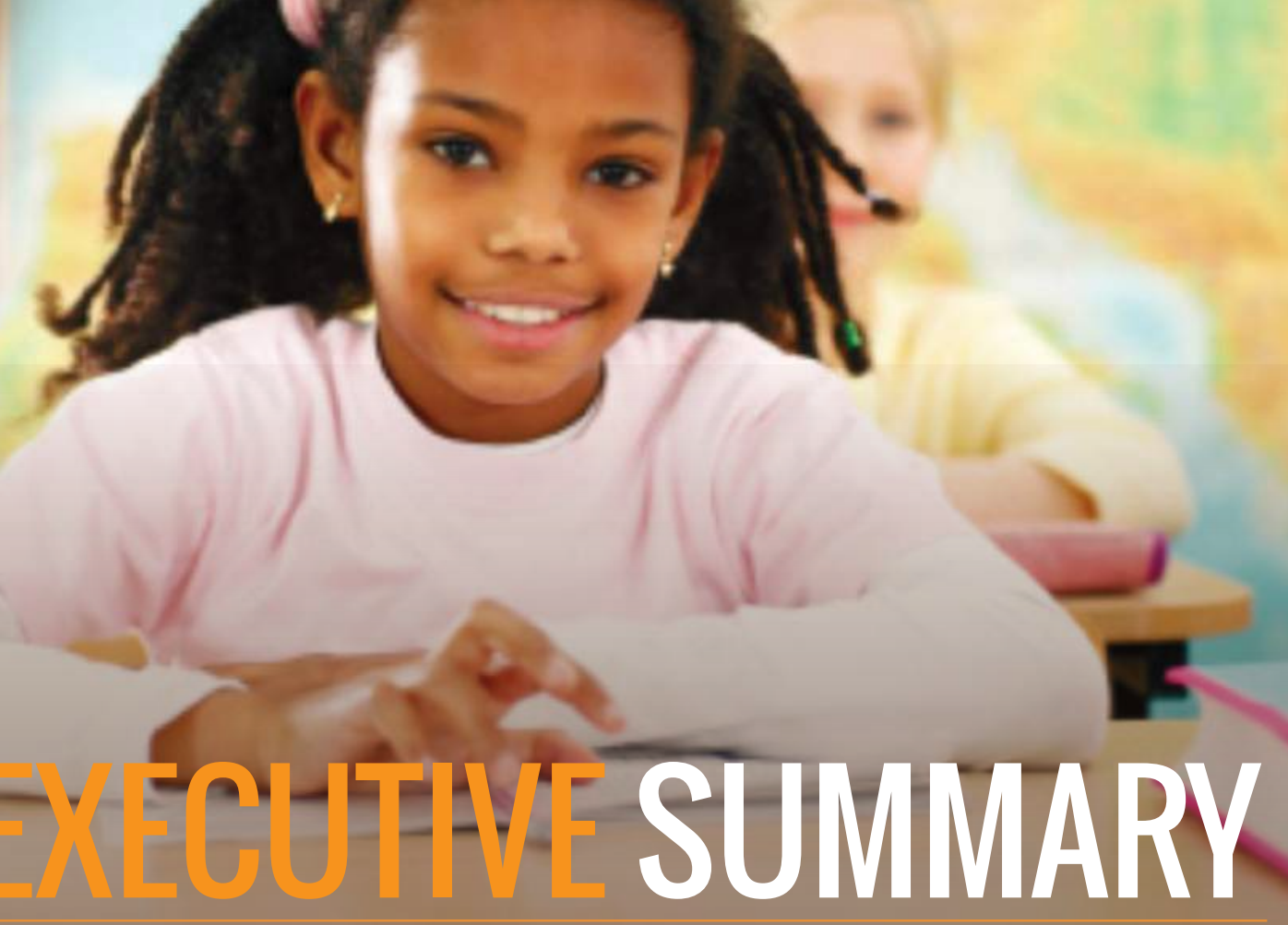

For girls, as with boys, the failure to receive a high school diploma often places individuals on a pathway to low-wage work, unemployment, and incarceration. The imposition of harsh disciplinary policies in public schools is a well-known risk factor for stunted educational opportunities for Black and Latino boys. Such punishments also negatively affect their female counterparts, as do other conditions in zero-tolerance schools. Yet, the existing research, data, and public policy debates often fail to address the degree to which girls face risks that are both similar to and different from those faced by boys.

This silence about at-risk girls is multidimensional and cross-institutional. The risks that Black and other girls of color confront rarely receive the full attention of researchers, advocates, policy makers, and funders. As a result, many educators, activists, and community members remain underinformed about the consequences of punitive school policies on girls as well as the distinctly gendered dynamics of zero-tolerance environments that limit their educational achievements. Black Girls Matter: Pushed Out, Overpoliced, and Underprotected endeavors to shine a spotlight on the various factors that direct girls of color down dead-end streets while obscuring their vulnerabilities. 


\section{KEY OBSERVATIONS}

Any effort to understand and intervene in the conditions confronting girls of color requires researchers, advocates, and stakeholders to listen to them and to document their stories. Moreover, data must be collected and analyzed to assess the gender disparities that exist within same-race cohorts as well as the racial disparities that exist within same-gender cohorts. If the challenges facing girls of color are to be addressed, then research and policy frameworks must move beyond the notion that all of the youth of color who are in crisis are boys, and that the concerns of white girls are indistinguishable from those of girls of color.

The research reflected in this report was designed to elevate the voices of Black girls and other girls of color affected by punitive policies so as to deepen our understanding of the ways they experience inhospitable educational environments and to produce recommendations designed to eliminate those inequities. Towards this end, the Center for Intersectionality and Social Policy Studies (CISPS) conducted focus groups and stakeholder interviews in Boston and New York City between September 2012 and August 2013. An analysis of reported data on school discipline was undertaken by the African American Policy Forum (AAPF) with the support of analysts at UCLA Law School. A summary of observations appears below:

IN NEW YORK AND BOSTON, BLACK BOYS AND GIRLS WERE SUBJECT TO LARGER ACHIEVEMENT GAPS AND HARSHER FORMS OF DISCIPLINE THAN THEIR WHITE COUNTERPARTS.

On some measures, the relative magnitude of the racial disparity between girls is greater than the disparity between boys.

\section{2}

AT-RISK YOUNG WOMEN DESCRIBE ZERO-TOLERANCE SCHOOLS AS CHAOTIC ENVIRONMENTS IN WHICH DISCIPLINE IS PRIORITIZED OVER EDUCATIONAL ATTAINMENT.

Participants indicated that zero-tolerance environments are neither safe nor conducive to learning. On the contrary, the emphasis on discipline leads many girls to become disengaged from the learning process and from school altogether. 
INCREASED LEVELS OF LAW ENFORCEMENT AND SECURITY PERSONNEL WITHIN SCHOOLS SOMETIMES MAKE GIRLS FEEL LESS SAFE AND LESS LIKELY TO ATTEND SCHOOL.

Some of the young women reported that their discomfort with security rituals such as passing through metal detectors was so great that they were dissuaded from coming to school at all.

\section{4}

GIRLS' ATTACHMENT AND SENSE OF BELONGING IN SCHOOL CAN BE UNDERMINED IF THEIR ACHIEVEMENTS ARE OVERLOOKED OR UNDERVALUED.

Research suggests that Black girls sometimes get less attention than their male counterparts early in their school careers because they are perceived to be more socially mature and self-reliant. The lack of attention can lead to "benign neglect" that may diminish school attachment in both high- and moderate-achieving female students.

5

PUNITIVERATHERTHANRESTORATIVERESPONSESTO CONFLICTCONTRIBUTES TO THE SEPARATION OF GIRLS FROM SCHOOL AND TO THEIR DISPROPORTIONATE INVOLVEMENT IN THE JUVENILE JUSTICE SYSTEM.

Several participants indicated that they were suspended or expelled - and some even prosecuted - for fighting in school. Conflicts that might have been better addressed through counseling, or other conflict resolution strategies were instead referred to the juvenile justice system.

\section{6}

THE FAILURE OF SCHOOLS TO INTERVENE IN SITUATIONS INVOLVING THE SEXUAL HARASSMENT AND BULLYING OF GIRLS CONTRIBUTES TO THEIR INSECURITY AT SCHOOL.

Stakeholders and participants noted that a heavy emphasis on discipline does little to curb harassing behavior in schools. Instead zero-tolerance policies may exacerbate the vulnerability of girls to harassing behavior because it penalizes them for defending themselves against such acts. 
GIRLS SOMETIMES RESORT TO "ACTING OUT" WHEN THEIR COUNSELING NEEDS ARE OVERLOOKED OR DISREGARDED.

In environments in which discipline is emphasized over counseling, girls who struggle with trauma and other unmet needs may come to the attention of school personnel only when their behavior leads to punishable offenses.

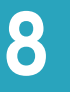

SCHOOL-AGE BLACK GIRLS EXPERIENCE A HIGH INCIDENCE OF INTERPERSONAL VIOLENCE.

Among the factors that disrupted some of the participants' ability to finish school was trauma associated with sexual assault and other forms of violence.

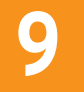

BLACKAND LATINA GIRLSAREOFTEN BURDENED WITHFAMILIALOBLIGATIONS THAT UNDERMINE THEIR CAPACITY TO ACHIEVE THEIR ACADEMIC GOALS.

Many stakeholders noted that girls were much more likely to be faced with caretaking responsibilities that compromised their ability to pursue their academic goals than their male counterparts.

10

PREGNANCY AND PARENTING MAKE IT DIFFICULT FOR GIRLS TO ENGAGE FULLY IN SCHOOL.

Pregnant girls are burdened by early parenthood in ways that boys are not. They are segregated from their peers and stigmatized in a manner that may undermine their attachment to school. 


\section{RECOMMENDATIONS}

Black Girls Matter: Pushed Out, Overpoliced, and Underprotected calls for the development of policies and programmatic interventions that address the challenges facing Black girls and other girls of color. Our recommendations - developed from interviews with young women directly affected by contemporary school policies and with stakeholders invested in their futures - are as follows:

$\triangle$ EXPAND EXISTING OPPORTUNITIES TO ENSURE THE INCLUSION OF BLACK GIRLS AND OTHER GIRLS OF COLOR IN POLICY RESEARCH, ADVOCACY, AND PROGRAMMATIC INTERVENTIONS.

ENSURE AN EQUITABLE APPROACH TO FUNDING THAT SUPPORTS THE NEEDS OF WOMEN AND GIRLS AS WELL AS THOSE OF MEN AND BOYS.

DEVELOP WAYS TO HELP GIRLS FEEL SAFE WITHOUT AN OVERRELIANCE ON PUNITIVE INTERVENTIONS.

$\triangle$ DEVELOPROBUSTPROTOCOLSTHATENSURETHAT SCHOOLPERSONNELENFORCEALLSTUDENTS' RIGHTS TO LEARN IN AN ENVIRONMENT FREE OF SEXUAL HARASSMENT AND BULLYING.

REVIEW AND REVISE POLICIES THAT FUNNEL GIRLS INTO THE JUVENILE JUSTICE SYSTEM.

DEVISE PROGRAMS THAT IDENTIFY THE SIGNS OF SEXUAL VICTIMIZATION IN ORDER TO SUPPORT GIRLS WHO HAVE BEEN TRAUMATIZED BY VIOLENCE.

$\triangle$ ADVANCE AND EXPAND PROGRAMS THAT SUPPORT GIRLS WHO ARE PREGNANT, PARENTING, OR OTHERWISE ASSUMING SIGNIFICANT FAMILIAL RESPONSIBILITIES.

URGE THE U.S. DEPARTMENT OF EDUCATION AND OTHER INFORMATION GATHERING INSTITUTIONS TO TAKE THE NECESSARY STEPS TO REFINE STATISTICAL REPORTING ON DISCIPLINARY MATTERS WHILE DISAGGREGATING ACHIEVEMENT DATA ALONG RACIAL AND GENDER LINES.

DEVELOP THE PUBLIC WILL TO ADDRESS THE CHALLENGES FACING BLACK GIRLS AND OTHER GIRLS OF COLOR THROUGH ELEVATING THEIR EXPERIENCES AND ENGAGING STAKEHOLDERS TO BECOME ACTIVELY INVOLVED IN THEIR WELFARE. 

Black girls face a variety of factors - historical, institutional, and social - that heighten their risk of underachievement and detachment from school, rendering them vulnerable to the lifelong consequences of dropping out. As with their male counterparts, the attitudes and institutional practices that limit opportunities for girls of color have deep historical roots.

Research and public policy debates, however, often fail to paint a nuanced picture that addresses the degree to which girls are vulnerable to many of the same factors faced by their male counterparts. For example, reports about zero-tolerance and push-out policies frequently fail to disaggregate or highlight the consequences of such policies for girls of color. Available information about the challenges that they face in regards to suspension, expulsion, and other disciplinary practices often go underreported, leading to the incorrect inference that their futures are not also at risk. This assumption obscures the fact that all too often girls are struggling in the shadows of public concern. For instance, the suspension and expulsion rates for Black girls far outpace the rates for other girls - and in some places, they outpace the rates of most boys. Yet, efforts to understand and respond to these disparate disciplinary patterns are few and far between. In fact, many of the gender-specific factors that contribute to low achievement and the separation of girls of color from school are often placed outside the dialogue about achievement and school discipline altogether.

Black Girls Matter ${ }^{14}$ attempts to highlight the educational, social, and economic factors that funnel Black girls and other girls of color onto pathways to nowhere and render their academic and professional vulnerabilities invisible. The report begins with an overview of the available data on the disproportionate rates of disciplinary action taken against girls of color in Boston and New York City. It then presents the key issues and concerns identified by young women of color in focus groups in Boston and New York that reveal why they either dropped out or were pushed out of school. It concludes with a list of preliminary recommendations for communities, stakeholders, funders, policymakers, and researchers. 



\section{THE HIDDE, ON BLACK GliRS: WHAT THE DATA SUGGEST}

Zero-tolerance policies not only promote out-of-school suspensions across all racial groups, but are also associated with the achievement gaps that exist between those groups. While there is limited research on how race, gender, and zero-tolerance policies interact to undermine the achievement and attachment of Black girls to school, existing data suggest that Black girls are profoundly affected by these concerns.

Although males are suspended in greater numbers than females overall, race and ethnicity turn out to be substantial risk factors for Black girls when they are compared to their white counterparts. Data released by the Department of Education for the 2011-2012 school year reveal that while Black males were suspended more than three times as often as their white counterparts, Black girls were suspended six times as often. [Figure 1] Only 2 percent of white females were subjected to exclusionary suspensions in comparison to 12 percent of Black girls. [Figure 2]

Our research confirms that the national pattern of racial disparity in the distribution of punitive discipline against Black students prevails in New York and in Boston. Discipline, suspension, and expulsion data for the Boston and New York school districts reveal that Black students face greater risks of suspension and expulsion than non-Black students. 


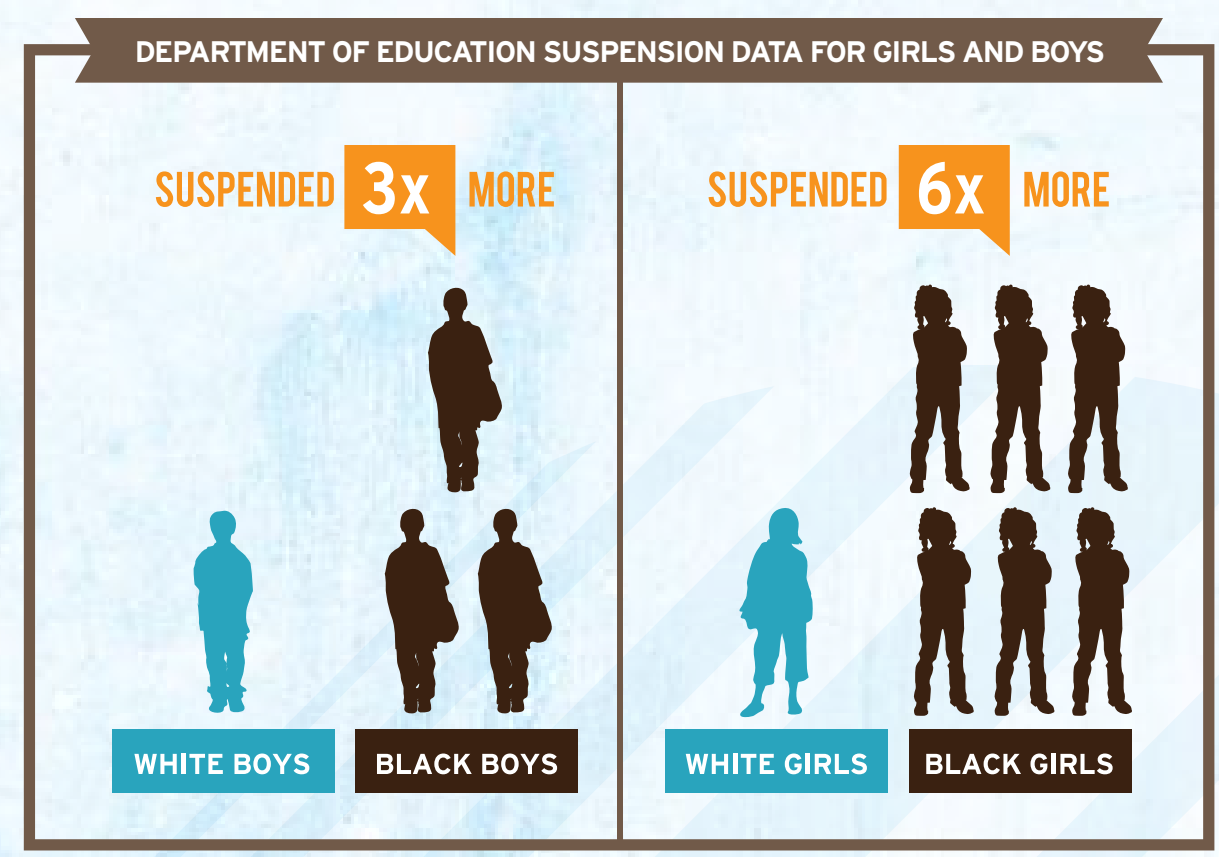

Figure 1: Intra-gender comparison of suspension rates. Department of Education, school year 2011-2012

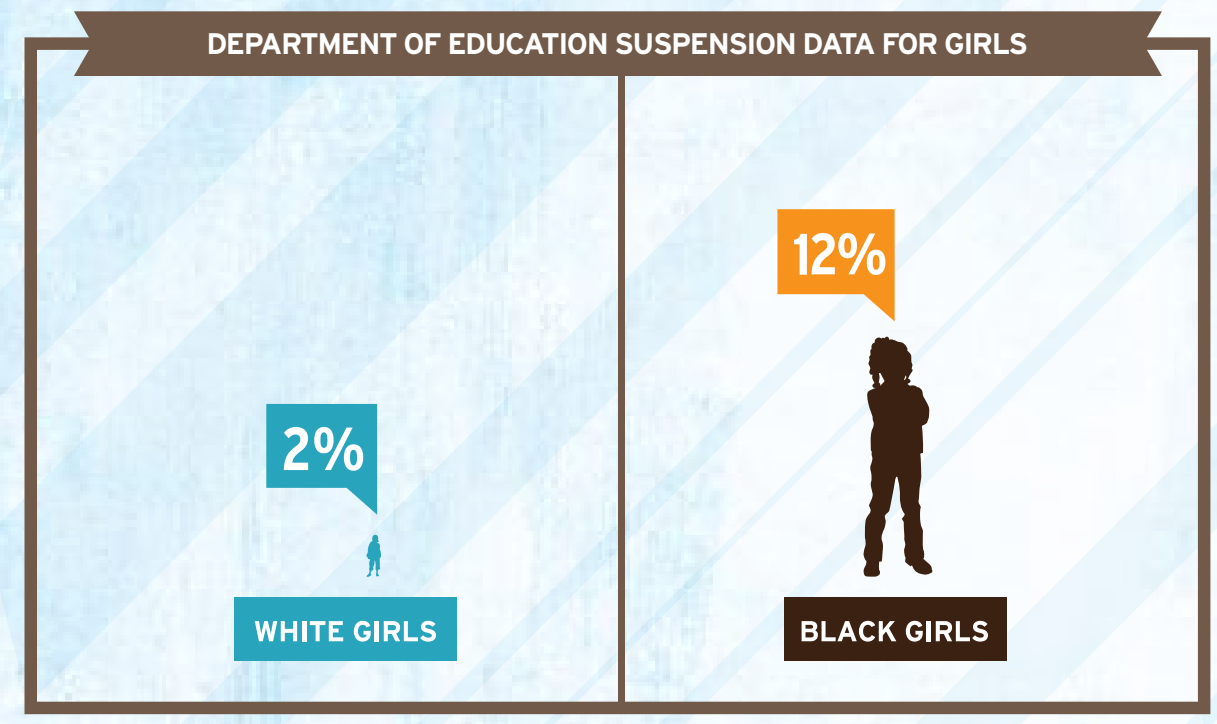

Figure 2: Intra-gender comparison of suspension rates. Depatment of Education, school year 2011-2012. Illustration represents bottom quartile of 100 percent scale.

Black boys are disciplined more than any other group, and are far more likely than white boys to be disciplined. Black girls are also punished more than other girls. In addition, the relative risk for suspension is higher for Black girls when compared to white girls than it is for Black boys when compared to white boys. As such, these data reveal that in some cases, race may be a more significant factor for females than it is for males. 


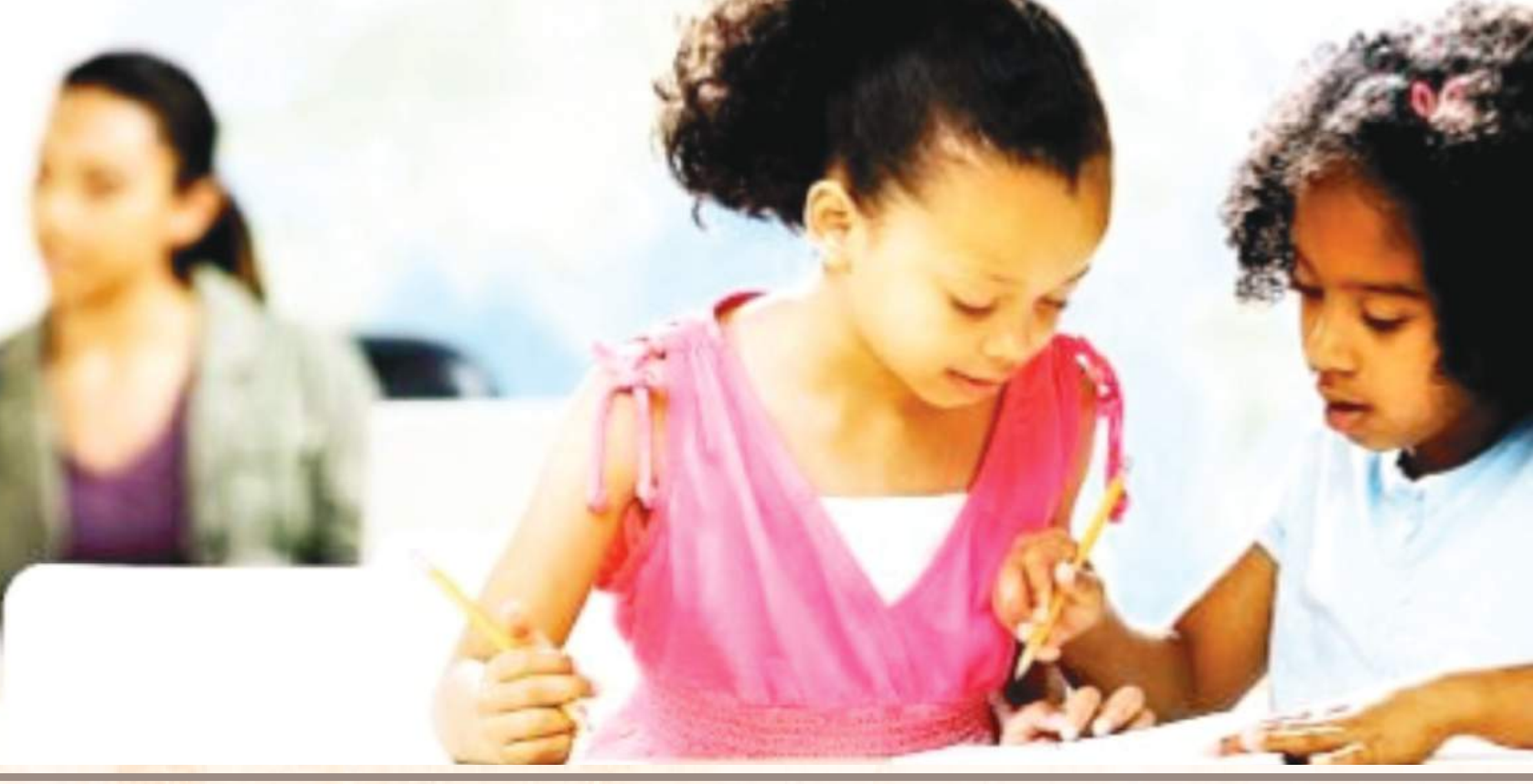

The particular disparities facing Black girls are largely unrecognized in the mainstream discourse about punitive policies in public education. Consequently, efforts to confront the challenge of ensuring equitable and fair opportunities for Black girls in school remain underdeveloped.

Understanding these inequities is particularly important given that the Boston and New York City public school districts are both large minoritymajority districts. [Table 1] The racial and ethnic enrollment ratios in these cities are, therefore, useful to keep in mind when considering the broader implications of the disparities we are examining in this report.

ENROLLMENT BY RACE AND ETHNICITY FOR NEW YORK AND BOSTON SCHOOL DISTRICTS

\begin{tabular}{l|c|c|c|c|c|c}
\hline DISTRICT & BLACK & ASIAN & HISPANIC & WHITE & OTHER & $\begin{array}{c}\text { TOTAL } \\
\text { ENROLLMENT } \\
(2013-2014)\end{array}$ \\
\hline BOSTON & $35 \%$ & $9 \%$ & $40 \%$ & $14 \%$ & $3 \%$ & 54,300 \\
\hline NEW YORK & $28 \%$ & $15 \%$ & $40 \%$ & $14 \%$ & $1 \%$ & $1,104,479$ \\
\hline
\end{tabular}

Table 1: Enrollment by race and ethncity for New York and Boston school districts, 2013-2014.

Sources: http://profiles.doe.mass.edu / http://schools.nyc.gov 


\section{DISCIPLINE RATES}

In Boston, Black girls comprised 61 percent of all girls disciplined, compared to white girls, who represented only five percent of such girls. Even though there were about three times as many Black girls as white girls enrolled, Black girls were eleven times more subjected to discipline than their white counterparts (340 vs. 30 cases, respectively). [Figures 3 and 5]

In New York City, Black girls represented 56 percent of all girls disciplined, compared to white girls, who represented only five percent of such girls. The enrollment of Black girls was about twice the rate of white girls but they were subjected to school discipline at ten times the rate of their white female counterparts $(9,076$ vs. 884 cases, respectively). [Figures 4 and 5]

As for males, in Boston, Black boys represented 57 percent of all boys who experienced discipline, compared to white boys, who represented only seven percent of all such boys. There were fewer than three times as many Black boys as white boys enrolled, but the number of Black boys disciplined was almost

PERCENTAGE OF ENROLLMENT VS. PERCENTAGE OF

STUDENTS DISCIPLINED BY RACE AND GENDER FOR BOSTON

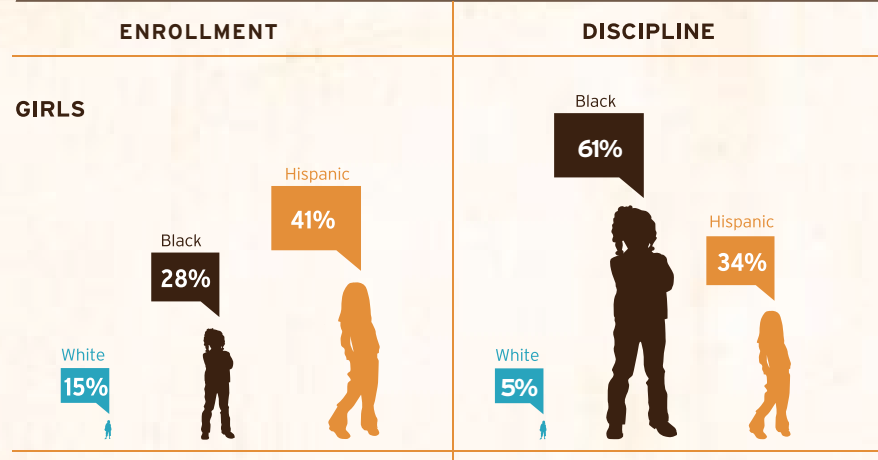

BOYs
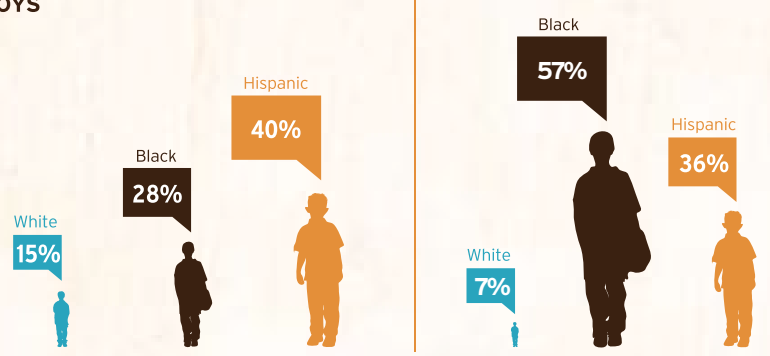

Figure 3: Intra-gender comparision of percentage enrollment vs. percentage of students disciplined, Boston school district, 2011-2012 school year

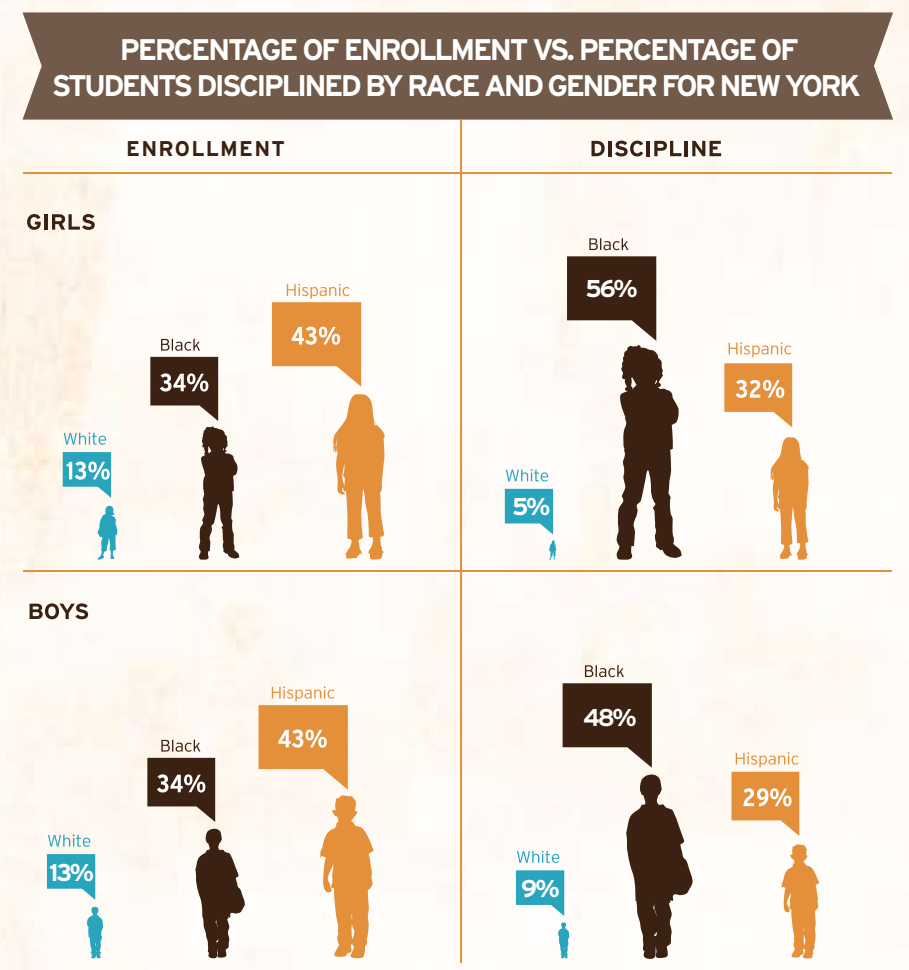

Figure 4: Intra-gender comparision of percentage enrollment vs. percentage of students disciplined, New York school district, 2011-2012 school year 


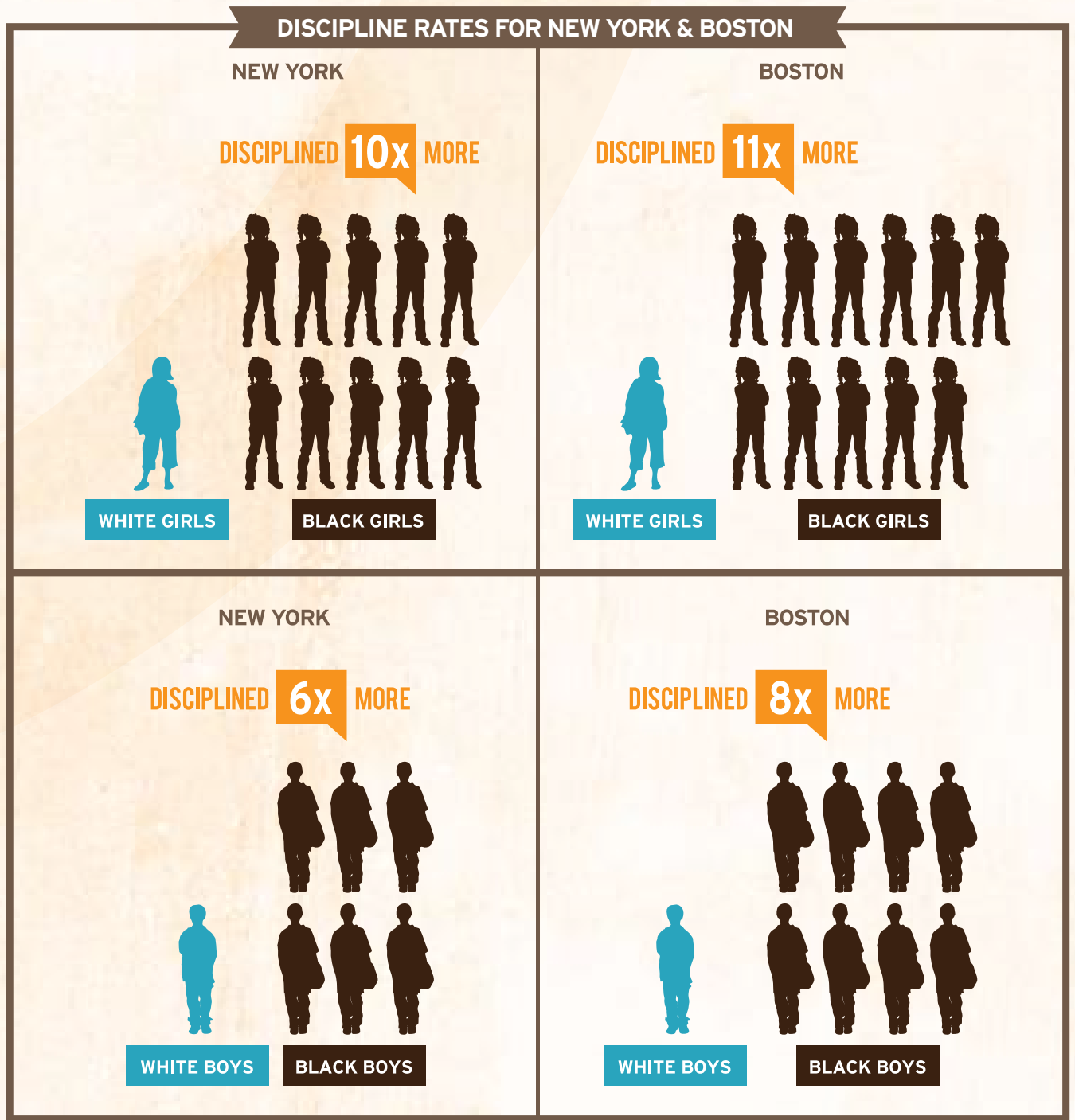

Figure 5: Intra-gender comparison of discipline rates in Boston and New York school districts, 2011-2012 school year

eight times the number of white boys disciplined (637 vs. 81 cases, respectively). [Figures 3 and 5]

In New York City, Black boys comprised 48 percent of all boys disciplined, while white boys represented only nine percent of all such boys. Even though there were about twice as many Black boys enrolled in the school system, the number of Black boys disciplined was six times the number of white boys $\left(13,823\right.$ cases vs. 2,541 cases, respectively). ${ }^{15}$ [Figures 4 and 5] 


\section{EXPULSION RATES}

In New York City during the 2011-2012 year, ninety percent of all the girls subjected to expulsion were Black. No white girls were expelled, and thus, no ratio can be calculated; but the magnitude of the disparity can be captured by simply imagining that one white girl had been expelled. Were that the case, the ratio would be 53:1.

In Boston, the percentages are also alarming. Of the total number of girls subjected to expulsion, 63 percent were Black; and no white girls were subject to expulsion. Again, assuming that one white girl had been expelled, Black girls would have been expelled at a rate of ten to one.

Meanwhile, Black boys were expelled at a rate ten times higher than white boys in New York, and six times higher than white boys in Boston. [Figure 6]
EXPULSION RATES FOR IN NEW YORK \& BOSTON

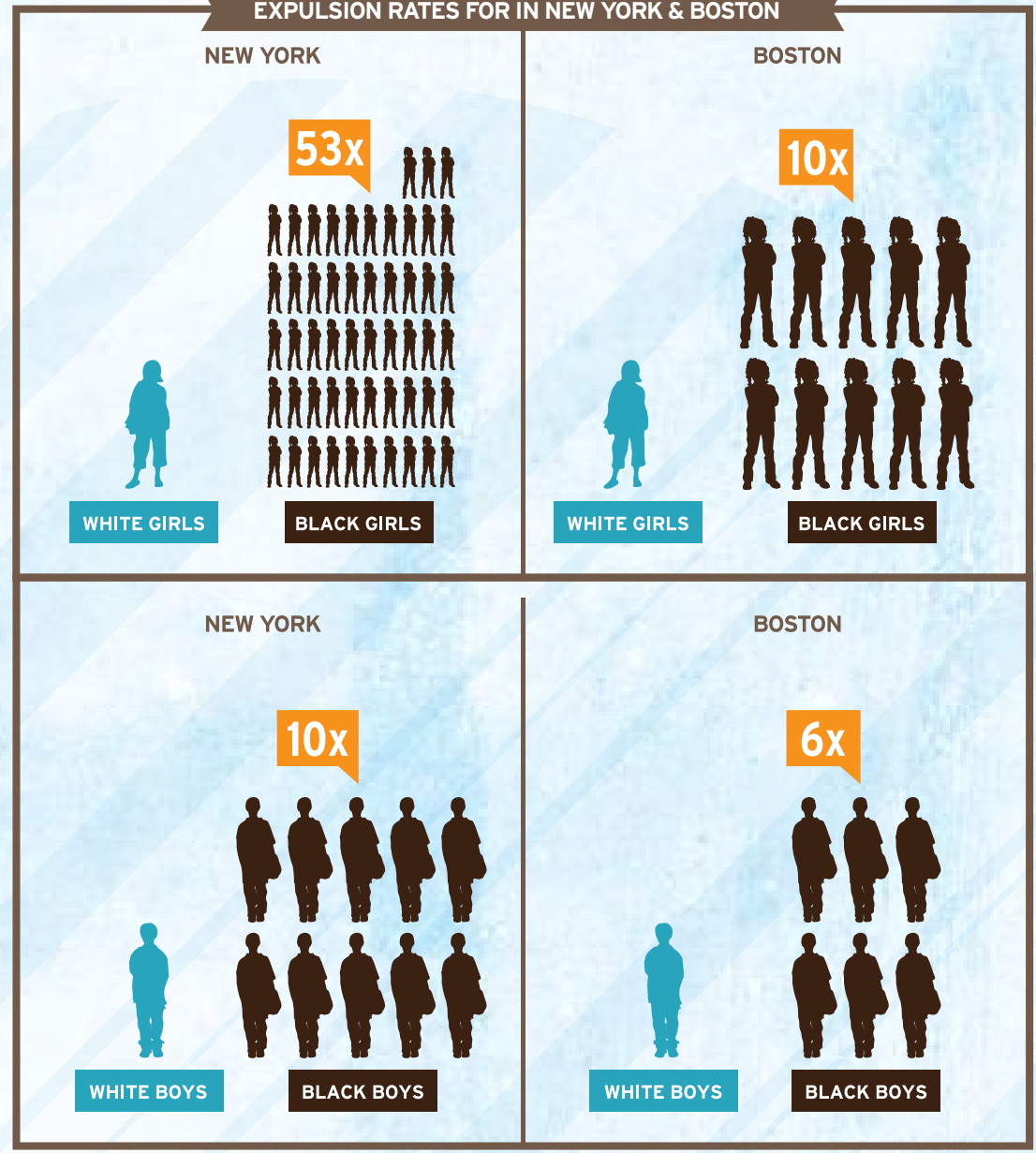

Figure 6 : Intra-gender comparison of expulsion rates. Boston and New York public school districts, 2011-2012 school year 


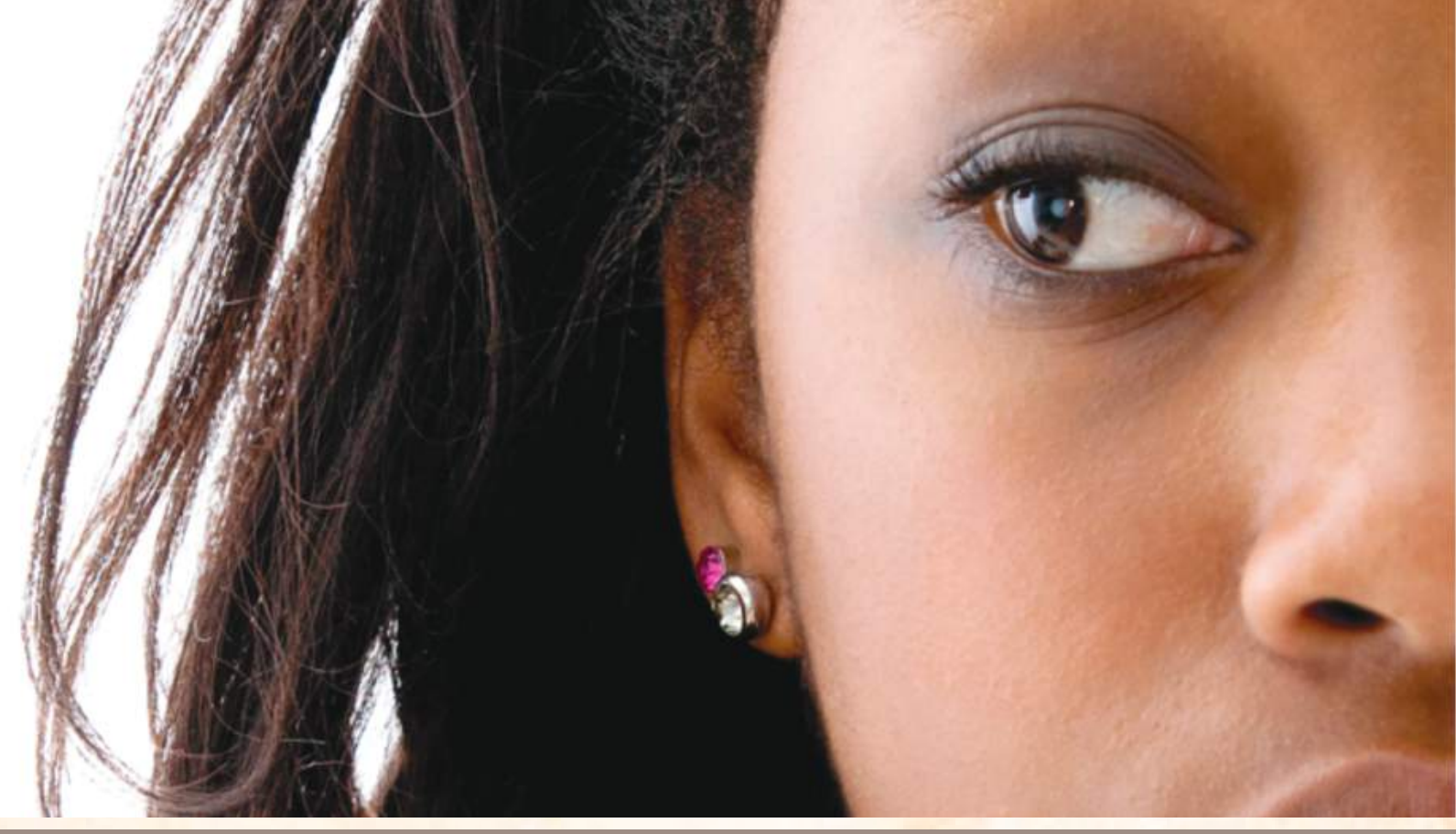

\section{SUSPENSION RATES}

During the same period, Black girls in New York were nearly ten times more likely to be suspended than their white counterparts and in Boston, they were suspended at almost twelve times the rate of white girls. In New York, Black boys were suspended at a rate five times that of white boys. In Boston, Black boys were 7.4 times more likely to be suspended than their white counterparts. [Figure 7]

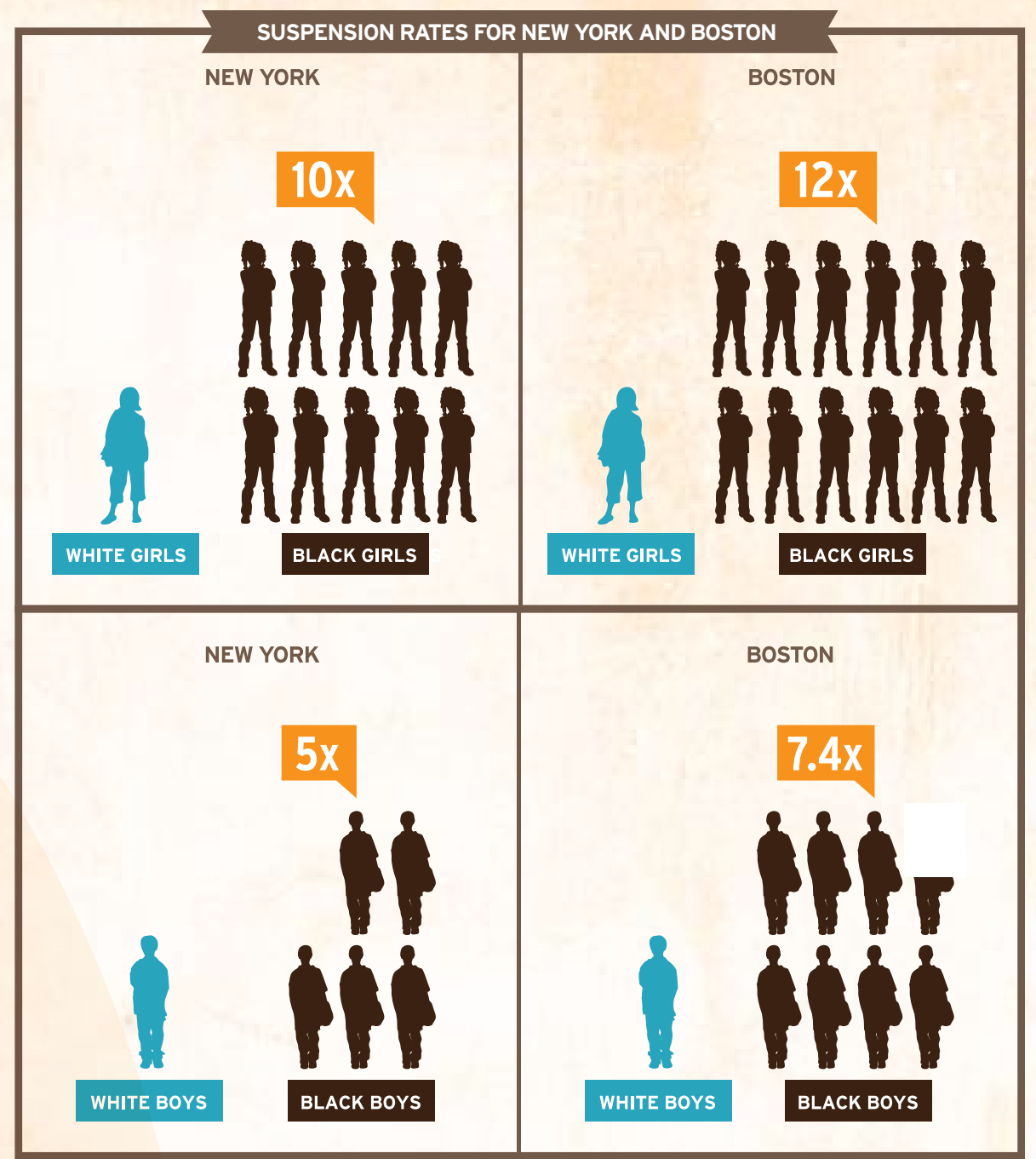

Figure 7: Intra-gender comparison of suspension rates. Boston and New York public school districts 2011-2012 school year 


\section{CONFRONTING THE PROBLEM}

While Black girls and Black boys share a common racialized risk of punishment in school, Black girls face a statistically greater chance of suspension and expulsion compared to other students of the same gender.

The prevalence of racial disparity in school discipline is well-known, but the greater racial disparity that Black female students face has not figured prominently in research or advocacy around school achievement. Factors that may contribute to the relative silence about this issue include methods of data gathering and reporting that fail to disaggregate information by both race and gender. Reports that do disaggregate data to reveal the status of boys often fail to report the available data on girls, leaving the impression among key stakeholders that Black girls are not facing significant racerelated obstacles in school.

In addition to data analysis and reporting practices, some researchers and advocates within this sector express concerns that acknowledging these differentials may contribute to divide and conquer strategies. Anxieties about intraracial competition in what is sometimes framed as a race to the bottom, as well as reservations about building interventions around deficits rather than assets, have contributed to the reluctance to explore gender disparities within race sensitive analyses.

Acknowledging the breadth of the punitive disparities facing Black girls, however, is a necessary first step in understanding and reversing the dynamics that contribute to disparate treatment. Where targeted interventions are necessary, they must be tailored to the unique ways that Black girls experience race and gender. Indicators may reflect that they share common challenges with their male or their female peers, but data may also point to the need for more focused responses. Comparisons of the relative rates of discipline are important indicators that there may be unique burdens that Black girls face to which interventions based on their male peers or white female counterparts may not respond. 
To the extent that public will to address these concerns turns on a communal commitment to dismantle race-related barriers to educational achievement, the gender and race-related burdens that Black girls and other girls of color face must be properly framed and understood.

\section{THE LITERATURE SUGGESTS THAT BLACK GIRLS FACE HIGHER RISKS OF SUSPENSION AND EXPULSION FOR SUBJECTIVE BEHAVIORAL INFRACTIONS.}

Investigations into why Black girls are much more likely to be harshly disciplined than other girls have been few and far between. The few researchers who work in this area repeatedly cite the need for more studies and better data. The available evidence, however, suggests that implicit biases, stereotyping, and other cultural factors may play a role. These dynamics may contribute to perceptions by decision makers that a Black girl has run afoul of institutional norms, and that punishment, rather than restorative or therapeutic responses, is warranted. ${ }^{16}$ Researchers have sought to measure the possibility that Black girls may be subject to harsher disciplinary interventions because they are perceived to be unruly, loud, and unmanageable. One study revealed that teachers sometimes exercised disciplinary measures against Black girls to encourage them to adopt more "acceptable" qualities of femininity, such as being quieter and more passive. ${ }^{17}$

\section{THE DISPROPORTIONATE SUSPENSION AND EXPULSION RATES FOR BLACK GIRLS REFLECT AN OVERLOOKED CRISIS THAT AFFECTS NOT ONLY THEIR LIFE CHANCES, BUT ALSO THE WELL-BEING OF THEIR FAMILIES, THEIR COMMUNITIES, AND SOCIETY AS A WHOLE.}

Girls who are suspended face a significantly greater likelihood of dropping out of school ${ }^{18}$ and are more likely to have contact with the juvenile justice system. ${ }^{19}$ The long-term consequences of dropping out are particularly troubling for Black as well as Latina girls, including a greater prevalence of low-wage work and unemployment. ${ }^{20}$ Because detachment from school carries so many negative consequences, efforts to reverse these patterns must be informed by a closer look at how girls experience the push and pull factors that shape their attachment to school. 
Girls of all races face severe economic consequences when they drop out of school. Moreover, the National Women's Law Center reported that the income gap between dropouts and high school graduates is greater for women than it is for men. ${ }^{21}$ This represents an acute problem for African American families due to the prevalence of single-wage-earning families headed by women. Given the economic dependence of so many Black children on a female wage earner, girls dropping out of high school is of critical socioeconomic concern.

\section{IN ADDITION TO DISCIPLINARY PROCEDURES, THE DATA SUGGEST THAT OTHER DYNAMICS - BOTH SOCIETAL AND INSTITUTIONAL - MAY CONTRIBUTE TO UNDERACHIEVEMENT AND DROPOUT RATES FOR BLACK GIRLS AND OTHER GIRLS OF COLOR.}

Factors that contribute to underachievement and dropout rates for Black girls and other girls of color may include the degree of social disorganization in their neighborhood, ${ }^{22}$ the quality of their relationships with peers, ${ }^{23}$ the safety risks associated with the physical space surrounding their schools, and the messages girls receive about the importance of their education at home. Moreover, dynamics that are more specifically gendered such as familial responsibilities, including parenting, caring for siblings, and domestic responsibilities - play a role in how well girls perform in school. However, perhaps the most significant gender-related factor that contributes to girls leaving school is pregnancy. ${ }^{24}$ One recent study found that only half ( 51 percent) of teen mothers finish high school by the age of 22 , compared to 89 percent of all other young women. ${ }^{25}$ 

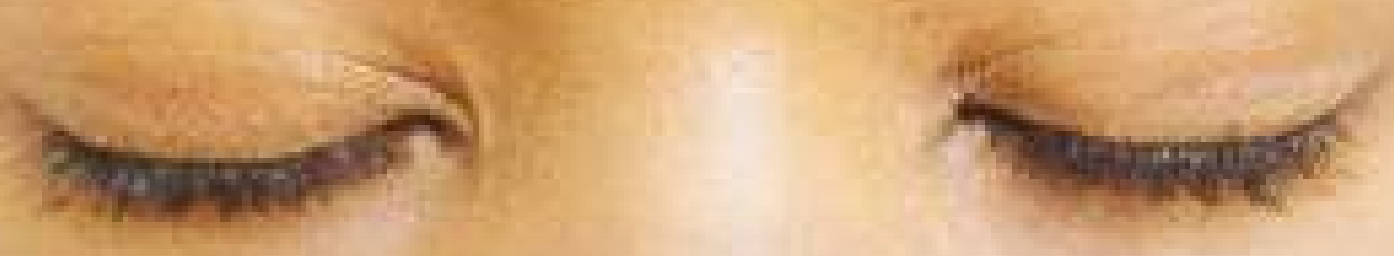

\section{WHAT GIRLS KNOW}

Although the available literature points to an array of factors that combine to shape the experiences of girls of color in school, a nuanced understanding of how at-risk girls become separated from school must be informed by their own testimony about their lives. To hear their voices, CISPS conducted focus groups in New York City and Boston between September 2012 and August 2013. ${ }^{26}$ The study sought to determine which factors contributed to the separation of girls and young women from school, and to assess what interventions were available to support girls. 
The scope of our focus groups and interviews was modest. As a result, the preliminary conclusions are not representative of the experiences of girls across the nation. They do, however, help us to identify more robust avenues of inquiry for future research.

Overall, the observations of participants and stakeholders in this report indicate that Black girls face obstacles both similar to and different from those confronted by their male counterparts. Participants in the focus groups articulated a broad range of concerns that contributed to their detachment from school, including caretaking responsibilities, financial hardship, living circumstances, homelessness, indifference, and the actual dislike of school. The girls also touched upon the particular dynamics of the schools themselves, including their perceptions that discipline and order are priorities that transcend the educational mission of the school. Other issues that contributed to their detachment from school include doubts about the relevance of the curricula and their teachers' cultural competence; the poor physical condition of their schools; violence, harassment, and abusive experiences within their schools; perceptions of unfair policies and disinterested teachers; the lack of effective counseling, conflict resolution, and problem-solving interventions; the absence of academic support and the appropriate incentives to complete school; and the threat of psychological and physical abuse, both within their schools and in their neighborhoods.

Stakeholders also identified these concerns and amplified them further. They drew attention to values, attitudes, and behaviors that affect dropout rates. They emphasized that these rates are affected by experiences that often begin in middle school. Particularly troubling were their observations that when girls sense that teachers do not value them or celebrate their achievements, they are more likely to leave school.

In the following pages, we offer excerpts from the rich dialogues that emerged in conversations with these young women and the stakeholders. 


\section{FOCUS GROUP \& STAKEHOLDER INTERVIEWS}

\section{OBSERVATIONS \& DIRECTIONS}

\section{AT-RISK YOUNG WOMEN DESCRIBE ZERO- TOLERANCE SCHOOLS AS CHAOTIC ENVIRONMENTS IN WHICH DISCIPLINE IS PRIORITIZED OVER EDUCATIONAL ATTAINMENT.}

Participants' comments suggest that zero-tolerance environments are neither safe nor nurturing settings within which to learn. To the contrary, the emphasis on discipline turns some girls off from school, leading them to become disengaged from the learning process and subject to separation from school altogether. Participants observed that the educational mission of school is typically subordinated to the mandate to discipline and punish:

The teachers don't care at all. They do sweep-ups in the hallway. If they see you in the hallway with no pass, you've got to leave automatically. They do it every day. Literally half of the school gets kicked out by the end of the day. 
Some goal-oriented young women reported dropping out because they have lost confidence that they can reach their academic aspirations in schools that fail to promote education. Some found the lack of security in regular track schools to be intolerable.

[Y]ou can't even sit in the classroom and learn anything 'cause everyone who would sit there would be rambunctious and retarded. I had enough. I actually want to go get my education. I didn't want a GED. I wanted to go somewhere with my life, so you know what? I'm not even going to be here.

Several participants linked their detachment from school to their belief that the teachers were not invested in their development or in teaching them at all:

You can tell because the teacher who just wants to get paid, if there's something wrong with you, they won't bother asking if you're OK, or if you need anything. . . .

Numerous participants described their interactions with teachers and counselors as unsatisfying and discouraging. When focus group participants were prompted to reflect on how their teachers and counselors perceived them, they generated common stereotypes that they believed shaped how they were treated:

They like 'can't be trusted, ' or 'they are loud and rowdy, ghetto,' and stuff like that. 'Ignorant.'

Some participants and stakeholders surmised that misconceptions about girls of color and cultural insensitivity contribute to the ways in which they are overdisciplined. One stakeholder hypothesized that cultural differences in the way that some Black girls express their identities contribute to the perception that they are defiant and that their behavior warrants punishment: 
Women of color are more likely to push back on things or they are going to talk a certain way and you have to understand what they are saying. You have to know how to deal with and not be upset with or be offended by it. ... [The girls] are going to question you. It's not that they are being disrespectful. It's they just want to know.

INCREASED LEVELS OF LAW ENFORCEMENT AND SECURITY PERSONNEL WITHIN SCHOOLS OFTEN MAKE GIRLS FEEL LESS SAFE AND LESS LIKELY TO ATTEND SCHOOL.

Perhaps counterintuitively, participants and stakeholders both faulted certain features of zero-tolerance policing as particularly problematic for girls, suggesting that they likely contributed to alienation and detachment from school.

The ever-present metal detectors were intimidating. Some of the young women reported that their discomfort with the security rituals was so great they were dissuaded from coming to school altogether:

Got right in front of my school, the long line for the metal detector. It was early too, so I was proud of that. But then I thought about it like, 'Oh God. I got to take off my clothes. Take my phone. I can't hide it.' I'm like, 'I'm not. I don't feel up to this.' 
It's like sexual harassment. Ok, it's not really sexual harassment. But you are very uncomfortable. You have to strip down to the T. . . You basically got to come to school naked. . . It's like uncomfortable. .. They got to search you. It feels like you're in jail. It's like they treat you like animals, because they think that's where you're going to end up.

Some stakeholders also maintained that highly disciplined school settings may exacerbate the imposition of certain gender norms, which then contribute to the use of draconian forms of punishment for behaviors considered out of character for girls:

If a girl does the same exact thing [as a boy] they are sent to the office right away and they miss out on whatever was happening in that class. And some of the girls did have this sense of frustration, that there is a different standard for girls' behavior versus boys. So boys seem to just get more looking the other way, or more tolerance of even the exact same behavior. Girls notice a gender gap in terms of teachers responding to bad behavior in the classroom.

I think that teachers come down harder on girls because they are just trying to prevent this behavior in them. . . . They kind of expect it from the boys. Whereas the boys get into a lot of mini fights - but not like girls fight - they calm them down and like, move on. There's more tolerance for their aggressive behavior, I guess you could say. But where girls do the same thing, they are punishing them to the letter of the law. 


\section{GIRLS' ATTACHMENT AND SENSE OF BELONGING}

IN SCHOOL CAN BE UNDERMINED IF THEIR ACHIEVEMENTS ARE OVERLOOKED OR UNDERVALUED.

Research outside the boundaries of the school discipline and achievement literature suggests that Black girls sometimes get less attention than their male counterparts early in their school careers and that they are perceived to be more socially mature and self-reliant. ${ }^{27}$ The lack of attention can become the touchstone of benign neglect that may diminish school attachment in high-achieving female students. One stakeholder noted:

What I have seen is that when girls do well in school it is kind of overlooked. Because despite everything [more is] still expected of them than the boys. So if the attention is always placed on the boys who do well, and that's what people in the building tend to highlight, girls who do well just kind of get overlooked. [T]here is rarely anything done to celebrate them or to encourage them to keep going. . . .

Because girls may not be perceived as problems or "in crisis," their needs for affirmation may be overlooked, leading some girls to gravitate toward unproductive pathways or to simply fall through the cracks.

[I] no one is celebrating with [you], then you kind of fade and then you have that other alternative culture that is waiting for you where you will be celebrated. ... [When] you realize that you will be celebrated if you are a well-known figure of prominence in the school for something else, then you kind of go in that direction and then it's kind of a spiral. 


\section{PUNITIVE RATHER THAN RESTORATIVE RESPONSES TO}

CONFLICT CONTRIBUTE TO THE SEPARATION OF GIRLS

FROM SCHOOL AND TO THEIR DISPROPORTIONATE

INVOLVEMENT IN THE JUVENILE JUSTICE SYSTEM.

Several participants indicated that they were suspended or expelled

- and some even prosecuted - for fighting in school. Conflicts that might have been better addressed through counseling, in-school suspension, or other conflict resolution strategies were instead referred to the juvenile justice system. Once the conflict was taken out of the hands of school administrators, girls encountered heavy penalties and repeated interventions.

Fighting is not cute because ... you realize . . getting arrested is not something you want to do. I got arrested when I was 16 for fighting. I learned my lesson. I got arrested again when I was 18 . It's not something you want to do.

Some participants indicated that they dropped out of school because of unsafe campuses and their fear that they might be prosecuted if they were forced to defend themselves.

I left because I was having a lot of drama with one particular senior. . . I I left because I didn't want to go to jail.

Respondents who recounted being suspended due to fighting noted that administrators, teachers, or counselors had not introduced conflict resolution strategies or other preventive measures. Skilled interventions might have redirected the conflicts that led to fighting into something less damaging to students' development and attachment to school. 
Not only did arrests for fighting and other school infractions constitute a direct route to juvenile supervision for some girls, but sometimes they were used by the school to justify expulsion. In neighborhoods where geographic distance made enrollment at another school impractical, the penalty for inappropriate behavior that otherwise might have warranted conflict management or counseling led to a complete separation from school. As one participant recounted:

I was only 16. I went to the police station. I stayed there. My mom came and got me. Yeah, she was mad. I had to go to court. At that school they were like, 'Oh, we don't want $A_{--} . .$. here no more, because she's . . . she's a threat to other kids.' I got expelled, and there's only one high school in [the city] and four elementary and one middle school. I was out of school for two years.

\section{5}

THE FAILURE OF SCHOOLS TO INTERVENE IN THE SEXUAL HARASSMENT AND BULLYING OF GIRLS CONTRIBUTES TO THEIR INSECURITY AT SCHOOL.

Participants and stakeholders addressed the consequences of sexually harassing behavior, physical and sexual assault, and bullying. The emphasis on harsh disciplinary measures did little to curb such behavior. In fact, zero-tolerance policies sometimes exacerbated the sense of vulnerability experienced by girls because they feared they would be penalized for defending themselves against aggressive behavior. One participant recalled that her long history of suspensions and expulsions began with what she believed to be an unfair punishment in response to assaultive behavior by a male classmate: 
This boy kept spitting those little spitballs through a straw at me while we were taking a test. I told the teacher, and he told him to stop, but he didn't. He kept on doing it. I yelled at him. He punched me in the face, like my eye. My eye was swollen. I don't remember if I fought him. That's how it ended. We both got suspended. I was like, 'Did I get suspended?' I was, like, a victim.

Stakeholders observed that teachers were some times unprepared to resolve matters associated with sexually harassing behavior.

It was remarkable how teachers have a culture of sweeping it under the rug. They will say that 'boys will be boys'; 'this is sexual awakening.' Yet they know all the gossip, they know all the stuff that is happening. ... [T]hey even talked about girls feeling shamed coming to school, like they can't concentrate because the boys are making comments - lewd comments - constantly pressuring them to have sex with them. Slapping their butts and bras, and just sort of forcing themselves on them against the wall or the locker. . .

Despite the fact that school officials are legally obligated to proscribe such behavior, one stakeholder observed that administrators and teachers often default to explanations that normalize sexual harassment. As a result, girls are left to face the consequences on their own:

There is this one story where a girl got a lot of attention from a boy, and he kept pressuring her for sex, and her father was trying to get teachers to help his daughter. He was saying that she can't go to school anymore if you don't do something, and the teachers were like 'good, take her out, she attracts too much attention from our boys.' I was waiting for another group of teachers to chime in, and they all kind of agreed. This isn't just an isolated incident. Teachers aren't the role models of gender equity. . . 


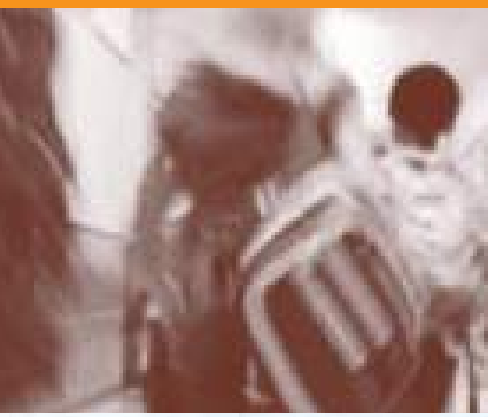

\section{GIRLS SOMETIMES RESORT TO “ACTING OUT" WHEN THEIR COUNSELING NEEDS ARE OVERLOOKED OR DISREGARDED.}

In environments in which discipline is foregrounded over counseling, girls who seek help in response to traumatic experiences or who have other unmet needs may gain the attention of school personnel only when they "show their face" (act out) in ways that prompt disciplinary intervention:

The only way they're going to know there's something wrong with you is if you show your face. If you try ... to go in there, try to sit there, one on one, they can automatically think you're there to waste time and not to go to class. It's like they shutting down on us.

This point was augmented by stakeholders who noted that some of the behavior that triggers the suspension or expulsion of girls may reflect the consequences of untreated trauma. While the problem of undiagnosed needs is not exclusive to girls, their concerns may be harder to address prior to a punishable act:

I think girls tend to not express the trauma ... and that is a big problem. In the school you focus on the people who are acting out so some are getting their needs met, but this doesn't mean that those that aren't acting out are not in need. It plays itself out later on. . . 


\section{7 SCHOOL-AGE BLACK GIRLS EXPERIENCE A HIGH INCIDENCE OF INTERPERSONAL VIOLENCE.}

Among the factors that disrupted the school experience were traumatic forms of sexual abuse. As one stakeholder noted:

It can be scary, you know. We definitely have a lot of child predators, and as our school began so early you'd have girls waiting for buses by themselves at 6:30 in the morning and it's dark outside. And they are the only ones out on the street, and they are worried. We've had several instances where girls were followed to school by strange men in a car, and they come to school and they are terrified. And yeah, unfortunate, very, very unfortunate... You're living in a low-income area. Our girls are a lot more vulnerable, and people do target them. And so they are often approached and solicited and, you know, all sorts of things they shouldn't have to endure.

The numerous forms of assault and harassment confronted by girls likely contribute to their detachment from school. Moreover, a disciplinary infraction related to post-traumatic stress can lead to their being pushed out of school. Young women who shared these experiences discussed what it meant for them to struggle to stay in school without adequate counseling and support. One participant recounted how untreated trauma related to having been raped led to her expulsion:

[T] he guidance counselor, I tried to talk to her. I wanted someone to listen to me, but she didn't listen. She was just like trying to figure me out, so I was like, 'forget it.' It all boiled up, and then I flipped on one of the teachers. Then I hit a teacher, so they kicked me out. 
In the current environment where discipline and testing are prioritized, resource constraints also undermine the schools' capacity to meet the emotional and developmental needs of their students. Explaining the limited capacity of school counselors, one stakeholder noted:

I don't think they have much time for guidance even if they wanted to. Even if they were inclined to, it seems to be the last priority in their job description.

BLACK AND LATINA GIRLS ARE OFTEN BURDENED WITH FAMILIAL OBLIGATIONS THAT UNDERMINE THEIR CAPACITY TO ACHIEVE THEIR ACADEMIC GOALS.

Many stakeholders noted that family caretaking responsibilities fell far more heavily on girls than boys. Shrinking budgets to support social welfare needs, along with the prevalence of addiction, incarceration, and deportation, have increased the caretaking burdens that many families face. These burdens, for the most part, fall upon females in the families. Multiple stakeholders noted that these additional responsibilities sometimes resulted in girls missing out on opportunities to participate in after-school activities. These burdens thus not only undermine their sense of attachment to their schools, but may deprive them of career-building opportunities.

Participants spoke about how their responsibilities to ensure the well-being of others caused them to leave school: 
My sister was on drugs. I've had my niece since she was three days old. I still raise her to this day. I put her on the school bus in the morning. That's my kid. You ask me, I tell people. . . in 10th grade, when all that happened, I didn't have anybody helping me.

Pregnancy and parenting make it difficult for girls to engage fully in school. Pregnant girls are burdened by early parenthood in ways that boys are not. They are segregated from their peers and stigmatized in a manner that may undermine their attachment to school.

You can be the father of three in the 9th grade, and then at the end of the day no one really cares, but if you're a girl, you know, those children are with you, they are seen. . .

I was mainly the talk because I was pregnant and I was also a freshman. I was in my second year of high school, which nobody really knew that. They talked about me.

Those who hoped to continue school despite their parenting responsibilities noted that the school programs permitting them to bring their children to school were unattractive options because the schools themselves were unsafe.

They want us to bring our kids but I don't feel safe. Why would I bring my child there? School's no place for your baby. 


\section{STAKEHOLDERS HIGHLIGHT THE NEED TO ADDRESS}

THE BARRIERS FACING GIRLS.

Stakeholders urged advocates and policy makers to acknowledge the social and cultural ecology in which boys and girls face interrelated and sometimes disparate obstacles.

One stakeholder noted that attention to girls of color is undermined by a prevailing understanding of the racial opportunity gap that is narrowly focused on race instead of gender:

Policy makers are more pressured to look at racial opportunity gaps rather than gender, which (reflects) the public perception and media hype that there is a level playing field for gender. It is not in vogue to deal with gender disparities, and even when I talk to the director about the achievement gap I was surprised that they don't look at gender. They look at race, ELL [English language learner], and disability ... they can't do gender.

Other stakeholders noted that in addition to reviewing school policies that undermine the attachment of girls of color to school, opportunities must be created for girls to think and grow together:

Girls need opportunities to take a deeper look and begin to question the messages they have been receiving. They are perfectly capable of doing that. But they need a venue to do that. And they need someone to have that conversation with.

I would say schools need to accommodate girls' needs to grow in more ways than just academically. If they taught them how to grow and achieve in ways other than academically, then they would also [grow] academically, but they have not had that connection yet. 


\section{MATCAMBEDOUY R RECOMMENDATIONSFOR ADDRESSINGTHENEEDSOFGIRLSOFCOLOR}

Our targeted effort to listen to girls of color and to the stakeholders who work with them confirmed that addressing the factors that contribute to their underachievement, push-out, and dropout from school requires a broader analytical prism. The recommendations below are informed by the voices of these young women and the stakeholders who are invested in their futures. These preliminary observations point toward the need for a wider range of information gathering and the development of policies sculpted to the contours of the lived experiences of girls of color.

\section{RECOMMENDATIONS}

\section{EXPAND EXISTING OPPORTUNITIES TO ENSURE THE INCLUSION OF BLACK GIRLS AND} OTHER GIRLS OF COLOR IN POLICY RESEARCH, ADVOCACY, AND PROGRAMMATIC INTERVENTIONS.

The erasure of the concerns of Black girls and other girls of color in these arenas has marginalized their needs to their disadvantage. More resources must be devoted toward understanding the intersections of race, gender, and other factors so as to address their effects on girls who fail to finish school. 
ENSURE AN EQUITABLE APPROACH TO FUNDING THAT SUPPORTS THE NEEDS OF WOMEN AND GIRLS AS WELL AS THOSE OF MEN AND BOYS.

Philanthropic entities must promote an equitable funding strategy for supporting women and girls of color. This is essential to ensuring that research, policy and service delivery entities are able to continue to meet the needs of men and boys as well as those of women and girls.

\section{DEVELOP ROBUST PROTOCOLS THAT ENSURE THAT SCHOOL PERSONNEL ENFORCE} ALL STUDENTS' RIGHTS TO AN ENVIRONMENT FREE OF SEXUAL HARASSMENT AND BULLYING.

Schools must take steps to educate both staff and students about what constitutes sexual harassment. Moreover, they should develop protocols to ensure that the appropriate interventions are available whenever accusations of sexual harassment arise.

\section{REVIEW AND REVISE POLICIES THAT FUNNEL GIRLS INTO THE JUVENILE JUSTICE SYSTEM.} The lack of counseling and other effective conflict intervention strategies leads many girls into contact with the juvenile justice system. Schools should review their current policies and develop more robust measures to ensure that student conflict is not unwarrantedly subjected to criminal sanctions.

\section{DEVISE PROGRAMS THAT IDENTIFY THE SIGNS OF SEXUAL VICTIMIZATION IN ORDER} TO SUPPORT GIRLS WHO HAVE BEEN TRAUMATIZED BY VIOLENCE.

Schools must train educators to identify signs of sexual abuse and respond with therapeutic interventions. In so doing, they should develop protocols and policies that streamline their responses to suspected instances of abuse.

ADVANCE AND EXPAND PROGRAMS THAT SUPPORT GIRLS WHO ARE PREGNANT, PARENTING, OR OTHERWISE ASSUMING SIGNIFICANT FAMILIAL RESPONSIBILITIES.

Lack of childcare, strict attendance policies, unsafe campuses, and untrained administrators contribute to school push-out of pregnant or parenting girls. Schools, stakeholders, and advocates must work to create policies that are sensitive to the needs of pregnant girls as well as girls who take on significant caretaking responsibilities. 
URGE THE U.S. DEPARTMENT OF EDUCATION AND OTHER INFORMATION GATHERING INSTITUTIONS TO TAKE THE NECESSARY STEPS TO REFINE STATISTICAL REPORTING ON DISCIPLINARY MATTERS WHILE DISAGGREGATING ACHIEVEMENT DATA ALONG RACIAL AND GENDER LINES.

To grasp the full dimensions of the educational crisis with greater clarity, it is essential that data be disaggregated by race and gender. While existing data can give us some sense of underlying patterns, the adoption of a common policy for collecting and reporting data by the Department of Education would enhance the scope and reliability of research in this field. Going forward, the Department should conduct race and gendersensitive analyses of its raw data and include that information in its annual reports.

\section{DEVELOP THE PUBLIC WILL TO ADDRESS THE CHALLENGES FACING BLACK GIRLS AND OTHER GIRLS OF COLOR THROUGH ELEVATING THEIR EXPERIENCES AND ENGAGING STAKEHOLDERS TO BECOME ACTIVELY INVOLVED IN THEIR WELFARE.}

Girls of color must have the opportunity to actively engage their teachers, school administrators, community leaders, families and other stakeholders about their experiences in school and in other institutions that shape their lives. Because the public discourse about girls of color has been so limited, town halls, community hearings, listening sessions and other opportunities to break the silence around their welfare must be encouraged. Leadership at all levels of government and within civil society should meet this challenge by acknowledging the importance of ensuring equitable opportunities for girls of color and by providing the resources necessary to secure these goals. 


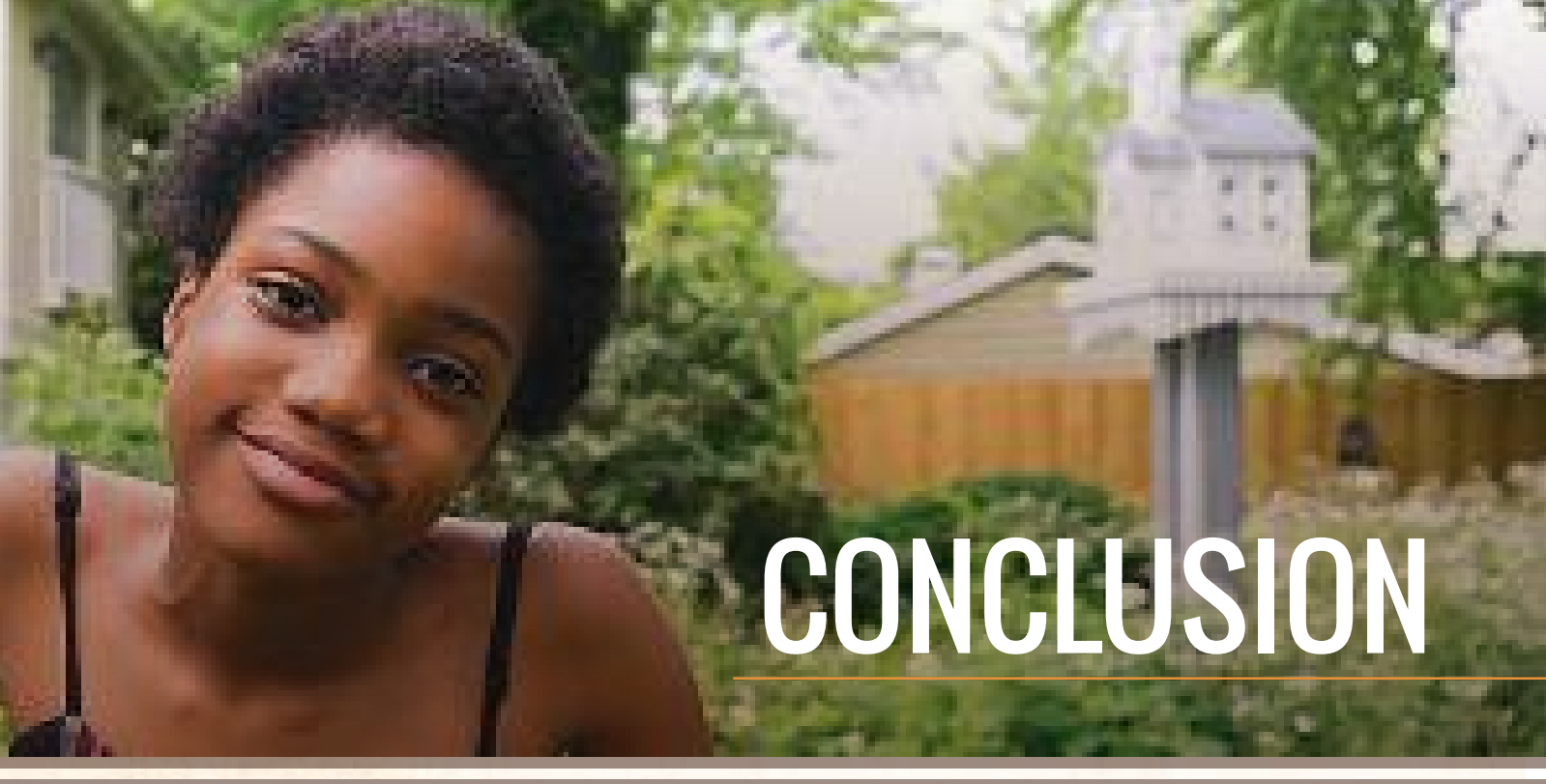

We can no longer afford to leave young women and girls of color at the margins of our concerns with respect to the achievement gap, the dropout crisis, and the school-to-prison pipeline. Instead, we must develop gender and race-conscious prisms that capture the vulnerabilities they experience today.

Our limited findings suggest that Black girls in New York and Boston sometimes encounter inhospitable conditions in institutions that are purportedly there to serve them. Like their male counterparts, many find themselves on pathways to diminished life opportunities without the promise of public and private interventions designed to focus on their needs.

We hope that this modest report begins to cast light on the lives of these girls. Ultimately, we hope that our effort to listen to Black girls is broadened to include other girls of color and is replicated nationwide. Ideally the conversation that Black Girls Matter engenders - both within communities of color and among philanthropists, stakeholders, policy makers, and advocates - will lead to more concerted efforts to include girls in studies about school discipline, push-out, and the pathways to underachievement, low-wage work, poverty, and incarceration.

We hope that ongoing efforts to address the crisis that faces boys of color will create opportunities to address the serious barriers facing their female peers. We encourage all stakeholders, researchers, funders, and concerned members of the public to broaden their understanding of the current crisis facing youth of color, and to commit to expanding both the conversation and the resources necessary to address these concerns. 


\section{RACE/ETHNICITY AND GENDER DISAGGREGATED STATISTICS}

The primary objective of this study was to integrate a gender lens into an analysis of the racial/ethnic disparities in school attachment and completion. Our approach was to separate males from females in each racial/ethnic category so that we could compare all groups against one another and then examine the disparate situations that people face within genders. We drew on nationwide noncompletion rates as well as graduation and discipline rates in the New York City and Boston public school districts.

\section{DISCIPLINE IN BOSTON AND NEW YORK CITY}

To analyze disciplinary patterns, we utilized data from the 2011-2012 school year released by the Office of Civil Rights Data Collection (OCRD) in 2014. These data were extracted using a tool from the OCRD website that generates its own reports according to the selected search terms for each district. The present report does not discuss the disciplining of students with Limited English Proficiency (LEP) or students with disabilities. However, those concerns are important factors to consider in future research.

There are many types of disciplinary measures used in public schools, including in-school suspension, out-of school suspension, and expulsion. This study uses the most expressive indicators for disciplinary action in both districts. In Boston, we considered the values for out-ofschool suspension, expulsion, referral to law enforcement, and schoolrelated arrests. In New York City, we examined in and out-of-school suspensions, expulsion, and referrals. The data allow comparison of differences among the gender-disaggregated racial/ethnic categories. 


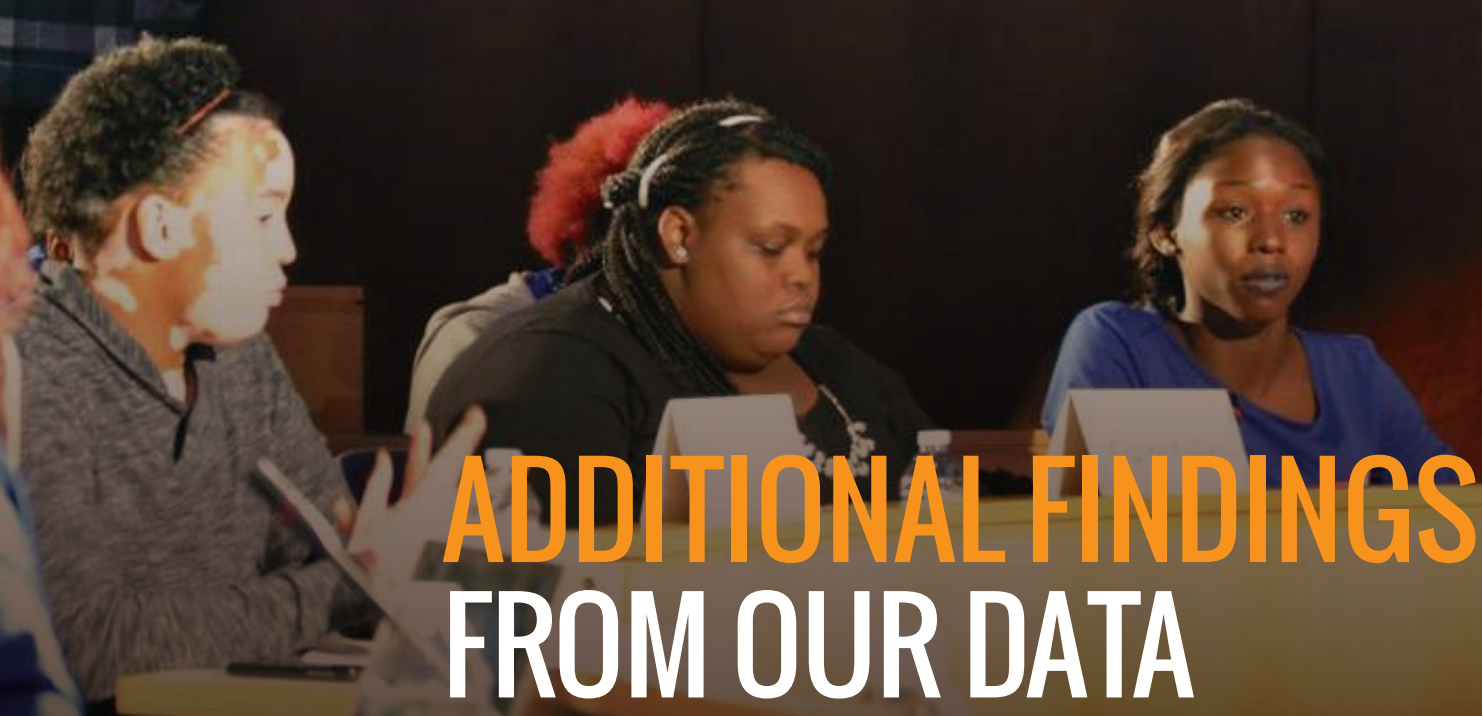

NONCOMPLETION RATES ${ }^{28}$

The magnitude of the disparities in non-completion rates between Black girls and white girls are consistently similar, and sometimes greater than the disparities between Black boys and their white male counterparts.

Nationally, after Latino boys, Latina girls have the highest noncompletion rates, surpassing both Black and white boys and girls.

$\triangle$ For all groups, noncompletion rates show a declining trend. The relative position of each group, however, has remained constant.

\section{RECOMMENDATIONS TO IMPROVE DATA}

There were numerous possible discrepancies in the data collected at the district, state, and national levels that made our work more difficult than necessary. The data was collected at different times, using an array of sampling techniques, reporting mechanisms and definitions of academic status and racial/ethnic categorization. Thus, our ability to use it to assess qualitative questions about the disproportionate use of harsh disciplinary measures on Black girls and to evaluate their levels of academic achievement are sometimes not as robust as we would prefer. With that reservation, we offer the following recommendations: 
Ongoing efforts to collect and analyze data on educational matters that focus on boys of color should embrace girls as well. Fortunately, this is an easy goal to achieve because the process of collecting data on boys already involves its disaggregation by gender and race/ethnicity.

All data produced for public consumption should provide the information required to analyze race/ethnic disparities both within and across genders. This process involves reporting disaggregated data by gender and race and supplying the necessary materials to test the statistical significance of the differences discovered.

Researchers and other data users should critically examine the language used to describe the data collected. Terms such as "dropout" and "graduation rate," for example, often connote failure or a lack of effort on the part of students rather than a focus on the role that school environments sometimes play in undermining the success of their students.

Researchers and data users should develop a single methodology to assess the most commonly used indicators and protocols for the academic achievement gap that can be implemented across disparate districts and states. Advocates and policy makers would then be better situated not only to identify the need for targeted interventions for different groups of boys and girls but also to measure the affect of such interventions.

The Office of Civil Rights Data Collection should continue to improve the quality of its data so that it generates results that its consumers can have more confidence in. This is especially important for intersectional research. Otherwise, the educational barriers faced by Black girls and other girls of color will remain largely invisible.

The National Center for Education Statistics (NCES) and other agencies should work together to improve the data collection process and to enhance the accessibility of the data that they synthesize. They should strive to eliminate the multiple and overlapping sources of data that currently exist, and the gaps in the evidence that is now collected. Ideally, they should facilitate a single entry point for the gathering of different sources of data. 


\section{ENDNOTES}

${ }^{1}$ Logan, Ruth-Manuel. "This Grandma Thinks The School District Went Too Far." News One. August 6, 2014. http://newsone.com/3042380/ kenji-roberts-henry-county-school-district/.

2 Klein, Rebecca. "Detroit Student Suspended For Rest Of The Year Over Pocketknife Found In Purse." The Huffington Post. October 15, 2014. http://www.huffingtonpost.com/2014/10/15/atiya-haynessuspended_n_5987140.html.

${ }^{3}$ Kaplan, Talia. "8-year-old Special Needs Student Handcuffed, Arrested for Tantrum at School." The Grio. March 13, 2013. http://thegrio. com/2013/03/08/8-year-old-special-needs-student-handcuffedarrested-for-tantrum-at-school/\#51100226.

${ }^{4}$ Kane, Alex. "Diabetic High School Girl Beaten by Police Officer and Arrested -- For Falling Asleep in Class." AlterNet. May 7, 2013. http:// www.alternet.org/news-amp-politics/diabetic-high-school-girl-beatenpolice-officer-and-arrested-falling-asleep-class.

${ }^{5}$ Klein, Rebecca. "Kiera Wilmot, 16, Arrested And Expelled For Explosive 'Science Experiment." The Huffington Post. May 1, 2013. http:// www. huffingtonpost.com/2013/05/01/kiera-wilmot-arrested-scienceexperiment_n_3194768.html.

${ }^{6}$ Kim, Clare. "Florida School Threatens to Expel Student Over 'Natural Hair'." MSNBC. November 26, 2013. http://www.msnbc.com/the-last-word-94.

${ }^{7}$ Herbert, Bob. "6-Year Olds Under Arrest." The New York Times. April 9, 2007. http://www.nytimes.com/2007/04/09/opinion/09herbert.html.

${ }^{8}$ Watson, Steve. "School Guards Break Child's Arm And Arrest Her For Dropping Cake." Info Wars. September 28, 2007. http://www.infowars. net/articles/september2007/280907Cake.htm.

9 Zero tolerance polices refer to school or district-wide policies that mandate predetermined, typically harsh consequences or punishments 
(such as suspension and expulsion) for a wide degree of rule violation.

10 "Black," sometimes but not always used interchangeably with African American, is capitalized as a proper noun on par with other panethnic designations, i.e. Asian, Latino, European, etc.

${ }^{11}$ While we use the term "girls of color" throughout, we draw primarily on data that reflect disparate outcomes for Black girls. Much of the existing data on disparate disciplinary outcomes in education and juvenile supervision show dramatically heightened risks for Black girls, and thus, the overall focus of the report pertains specifically to them. The report also includes data on Latinas, recognizing that there is an overlap in both the categories of Black and Latina, and also in their experiences.

Data also suggest that Native American girls and some Asian American girls also face disparate outcomes (see:http://www.apa.org/ed/ resources/racial-disparities.pdf). A broadened research agenda must include targeted analysis of girls of color, including girls with disabilities, and gender-nonconforming girls.

12 "Overpoliced and Underprotected: Women, Race, and Criminalization." UCLA School of Law, January 27-28, 2012. For an overview, see Crenshaw, Kimberlé W. "From Private Violence to Mass Incarceration: Thinking Intersectionally About Women, Race, and Social Control." UCLA Law Review 59, no. 6 (2012): 1418-1472.

13 The Bureau of Justice Statistics estimates that 42 percent of the female state inmate population has not received a high school diploma or GED, and 28 percent of female violent offenders are juveniles, a rate similar to that of males (see Caroline Wolf Harlow. "Education and Correctional Populations." US Department of Justice, Office of Justice Programs. Washington, DC. (2003). available at (https://youthbuild.org/ sites/default/files/news/2012/08/3022/ecp.pdf.); Greenfield, Lawrence A. and Tracy L. Snell. "Women Offenders." US Department of Justice, Office of Justice Programs Washington, DC. (2000). available at (http:// www.bjs.gov/content/pub/pdf/wo.pdf).

${ }^{14}$ This report summarizes a more detailed report of the push-out factors observed in Boston and New York. Additional cities are currently under review and a subsequent compilation of multi-city data will be included in a forthcoming report. 
${ }^{15}$ There are many types of disciplinary measures used in public schools, including in-school suspension, out-of-school suspension, and expulsion. This study uses the most expressive indicators for disciplinary action in Boston and New York school districts. In Boston, we considered the values for out-of-school suspension, expulsion, referral to law enforcement, and school-related arrests. In New York City, we examined in and out-of-school suspensions, expulsion, and referrals.

We note here that there are concerns about the accuracy of data provided to OCR by NYC Public Schools, particularly with respect to the low number of suspensions and discipline actions reported. The data may under-report disciplinary actions in NYC.

16 Downey, Douglas B., and Shana Pribesh. "When Race Matters: Teachers' Evaluations of Students' Classroom Behavior." Sociology of Education 77, no. 4 (2004): 267-82. (connecting implicit bias to teachers' disproportionate discipline of minority students); Blake, Jamilia J., Bettie Ray Butler, Chance W. Lewis, and Alicia Darensbourg. "Unmasking the Inequitable Discipline Experiences of Urban Black Girls: Implications for Urban Educational Stakeholders." The Urban Review 43, no. 1 (2011): 90-94.

${ }^{17}$ See generally Blake, Jamilia J., Bettie Ray Butler, Chance W. Lewis, and Alicia Darensbourg. "Unmasking the Inequitable Discipline Experiences of Urban Black Girls: Implications for Urban Educational Stakeholders." The Urban Review 43, no. 1 (2011): 90-94.

18 Christle, Chistine A., C. Michael Nelson, and Kristine Jolivette. "School Characteristics Related to the Use of Suspension." Education \& Treatment of Children 27, no. 4 (2004): 509-521. ("According to the Civil Rights project (2000) suspension sends a 'push-out' message to students, and suspension is one of the top reasons for dropping out of school.").

19 Nicholson-Crotty, Sean, Zachary Birchmeier, and David Valentine. "Exploring The Impact Of School Discipline On Racial Disproportion In The Juvenile Justice System." Social Science Quarterly 90, no. 4 (2009): 1003-018. ("In the context of this study, this suggests that black youth are referred into the juvenile justice system at higher rates, in part, because they are more likely to spend their days on the streets due to 
suspension and are, therefore, more likely to come into contact with police relative to their white counterparts."); see also, Levick, Marsha L. and Francine T. Sherman. "When Individual Differences Demand Equal Treatment: An Equal Rights Approach to the Special Needs of Girls in the Juvenile Justice System." Wisconsin Women's Law Journal 18 (2003): 18, no. 1, available at (http://works.bepress.com/francine_ sherman/66/); Kakar, Suman, Marie- Luise Friedemann, and Linda Peck. "Girls in Detention: The Results of Focus Group Discussion Interviews and Official Records Review." Journal of Contemporary Criminal Justice 18, no. 1 (2002): 57-73. available at (http://www.sagepub.com/prccj3/ overviews/pdfs/Kakar.pdf).

${ }^{20}$ U.S. Dep't of Labor, Bureau of Labor Statistics (2014). Employment Projections, available at (http://www.bls.gov/emp/ep_chart_001.htm).

${ }^{21}$ National Women's Law Center, (2007). When Girls Don't Graduate We All Fail: A Call to Improve High School Graduation Rates for Girls. Washington DC, available at

(http://www.nwlc.org/sites/default/files/pdfs/when_girls_dont_ graduate.pdf).

${ }^{22}$ Bowen, Natasha K., Gary L. Bowen, and William B. Ware. "Neighborhood Social Disorganization, Families, and the Educational Behavior of Adolescents." Journal of Adolescent Research 17, no. 5 (2002): 468-90. (finding that perceived neighborhood social disorganization exerts a larger effect on educational behavior than family processes).

${ }^{23}$ See, e.g., You, Sukkyung. "Peer Influence and Adolescents' School Engagement." Procedia - Social and Behavioral Sciences 29, no. 1 (2011): 829-35.

24 Gunn-Wright, Rhiana, and Barbara Gault. "Improving Outcomes for Marginalized Girls in the Secondary Education and Workforce Development Systems." Georgetown Journal on Poverty Law \& Policy 20, no. 2 (2013): 351, 353-7.

${ }^{25}$ The National Campaign to Prevent Teen and Unplanned Pregnancy, Teen Childbearing, Education, and Economic Wellbeing, (2012). Why It Matters: Teen Childbearing, Education, and Economic Wellbeing, available at (https://thenationalcampaign.org/sites/default/files/resource-primarydownload/childbearing-education-economicwellbeing.pdf). 
26 Using semi-structured focus groups and interviews, our research team engaged 15 adult stakeholders and 20 young women.

In New York City, all of the focus group participants were Black. Over half of the paticipants were young women who had dropped out of high school. Of those young women, 75 percent have since returned to complete their education, either through alternative education or via traditional high school. 29 percent of the focus group participants were mothers of small children under the age of five-years-old.

In Boston, of the focus group participants who chose to self identify, the majority were Black (78 percent). In addition, there was one Native American participant and two Latina participants. All of the young women had dropped out of school or had been expelled from school. All were currently enrolled in either an alternative high school, public charter school, or a school-to-work program. Fifteen percent of the Boston focus group participants identified themselves as being mothers or guardians of small children.

All fifteen key stakeholder interviewees were individuals with direct experience as school administrators, teachers, researchers, parents, former students and advocates and/or service providers to young women who had dropped out of school.

${ }^{27}$ Scott-Jones, Diane, and Maxine L. Clark. "The School Experiences of Black Girls: The Interaction of Gender, Race, and Socioeconomic Status." Phi Delta Kappan 67, no. 7 (1986): 520-26.

${ }^{28}$ National annual dropout rates were taken from the National Center for Education Statistics (https://nces.ed.gov). Data on graduation rates at the district level were extracted from The New York City Department of Education (http://schools.nyc.gov/default.htm) and the Massachusetts Department of Elementary and Secondary Education (ESE) (http://www.doe.mass. edu). Statistics on discipline were calculated using the US Department of Education Civil Rights Data Collection (OCR) (http://ocrdata.ed.gov). 
